\title{
1 How craton margins are preserved: Insights from geodynamic models
}

3 Claire A. Currie ${ }^{1}$ and Jolante van Wijk ${ }^{2}$

4

$5 \quad{ }^{1}$ Department of Physics, University of Alberta, Edmonton AB, Canada

$6 \quad{ }^{2}$ Department of Earth and Environmental Science, New Mexico Institute of Mining and

7 Technology, Socorro NM, USA

8

9

10

11 Corresponding Author:

12 Claire Currie

13 Department of Physics

$14 \quad$ University of Alberta

15 Edmonton $\mathrm{AB}$

16 T6G 2E1

17 Email: claire.currie@ualberta.ca

18 Phone: (780) 492-1062

19 
20 Abstract. Lateral variations in lithosphere thickness are observed in many continental regions,

21 especially at the boundary between the ancient cratonic core and the adjacent more juvenile

22 lithosphere. In some places, such as the North America craton margin in western Canada and the

23 Sorgenfrei-Tornquist Zone in northern Europe, the transition in lithosphere thickness has a steep

24 gradient $\left(>45^{\circ}\right)$ and it appears to be a long-lived feature (at least $50 \mathrm{Ma}$ ). We use thermal-

25 mechanical numerical models to address the dynamics of lithospheric thickness changes on

26 timescales of $100 \mathrm{Ma}$. Models start with the juxtaposition of $60 \mathrm{~km}$ thick lithosphere ("mobile

27 belt") and $160 \mathrm{~km}$ thick lithosphere (“craton"). In the reference model, all mantle materials have

28 a damp olivine rheology and a density comparable to primitive mantle. With this configuration,

29 edge-driven mantle convection occurs at the craton boundary, resulting in a lateral smoothing of

30 the thickness transition. The density and rheology of the craton mantle lithosphere are then

31 varied to approximate changes in composition and water content. For all densities, a steep

32 transition is maintained only if the craton strength is 5-50 times stronger than the reference damp

33 olivine. If dry olivine is an upper limit on strength, only cratonic mantle with moderate

34 compositional buoyancy $\left(20-40 \mathrm{~kg} / \mathrm{m}^{3}\right.$ less dense than primitive mantle) remains stable. At

35 higher densities, the thick lithosphere is eroded through downwellings, and the craton margin

36 migrates inboard. Conversely, a compositionally buoyant craton destabilises through lateral

37 spreading below the mobile belt.

39 Keywords: cratons; continental lithosphere; numerical models; gravitational instability; edge-

40 driven convection 


\section{Highlights}

43 - lateral changes in continental lithosphere thickness induce edge-driven convection

44 - thick cratonic lithosphere is readily eroded if it is weak due to partial hydration

45 - steep cratonic margins are preserved for at least $100 \mathrm{Ma}$ if the lithosphere is dry

46 - moderate compositional buoyancy enhances margin stability

47 


\section{Introduction}

Since Dana (1875), it has been recognised that within Earth's continental lithosphere, a

50 number of Archaean and Proterozoic-aged blocks have been preserved for sometimes billions of

51 years, surviving multiple plate tectonic cycles (Figure 1). The Archaean craton fragments in

52 North America and central Eurasia are surrounded by early Proterozoic lithosphere, while in

53 other locations (Africa, South America, western North America, western Europe), Archaean

54 cratons may be juxtaposed against lithosphere that varies in age from Paleozoic to Cenozoic.

55 Archaean and Proterozoic cratons that are surrounded by younger mobile belts are believed to

56 survive plate tectonic cycles because the mobile belts are weaker than the cratonic lithospheric

57 blocks, and the mobile belts are therefore preferred locations for continental rupture during the

58 supercontinent cycle (Audet and Bürgman, 2011). This is not the only inferred role of mobile

59 belts in craton preservation: they may also protect cratons from mantle-derived stresses

60 (Lenardic et al., 2000), shielding them from erosional effects of the mantle wind associated with

61 mantle convection and plate motions. Removal of the mobile belt would then facilitate craton

62 recycling (Lenardic et al., 2000).

63 While protected by mobile belts, cratons are further shielded from destruction by their

64 strength and buoyancy. Doin et al. (1997) and Wang et al. (2014) find that preservation of

65 cratons is promoted by rheologically strong roots. Cratons are also inferred to possess a

66 lithospheric root with a density lower than the asthenospheric density. The thermal thickness

67 (depth to the $1300^{\circ} \mathrm{C}$ isotherm) of Archaean and Proterozoic lithosphere varies between about

68200 and $350 \mathrm{~km}$ (Artemieva and Mooney, 2001), where thicker lithosphere corresponds to older

69 (Archaean) lithosphere. Combining average elevation of Archaean and Proterozoic lithosphere

70 with their thermal gradients, and assuming isostatic equilibrium, suggests that mantle lithosphere 
71 of Proterozoic and Archaean ages must have a density that is $\sim 0.5-1.5 \%$ lower than the density of

72 the underlying asthenosphere (Artemieva and Mooney, 2001). This is consistent with xenolith

73 studies that show that Proterozoic and Archaean mantle lithosphere can be less dense than

74 primitive mantle (e.g., Poudjom Djomani et al., 2001; Lee et al., 2011). The strong and buoyant

75 nature of the cratonic mantle is thought to generally prevent its destruction by delamination or

76 Rayleigh-Taylor-type instabilities, although there is abundant evidence that craton destruction

77 has occurred in geologic history (Li et al., 2015 for an overview).

78 Several mechanisms have been proposed to explain craton destruction from below. For

79 example, Gorczyk et al. (2012) show in a geodynamic modeling study that lateral variations in

80 mantle lithosphere rheology may trigger Rayleigh-Taylor instabilities in intra-cratonic regions,

81 resulting in craton mantle lithosphere removal. This may have contributed to destruction of the

82 central Australia craton (Gorczyk et al., 2012). Refertilisation of cratonic mantle lithosphere

83 (Tang et al., 2013) will reduce its viscosity while increasing its density (Hu et al., 2000; Li et al.,

84 2008), promoting delamination. The Colorado Plateau (Levander et al., 2011), Wyoming craton

85 (Boyd et al., 2004) and North China craton (Gao et al., 2004; Wu et al., 2005; Zhao and Zheng,

86 2007) are thought to have been thinned by this mechanism. Thermo-chemical destruction by

87 mantle flow may be effective after the thermal boundary layer of the lithosphere has been eroded

88 by asthenospheric shear (Cooper and Conrad, 2009).

89 Asthenosphere erosion may also affect the marginal regions of cratons, resulting in craton

90 destruction from its side. The North China and Yangtze cratons were both weakened along their

91 margins before destruction (Li et al., 2015). Miocene erosion of Colorado Plateau lithosphere by

92 small-scale upper mantle convection (Karlstrom et al., 2008; van Wijk et al., 2010) may have

93 removed mantle lithosphere material from the edge of this Proterozoic block. Also, the western 
94 side of the North American craton may have been eroded by edge-driven convection (Hardebol

95 et al., 2012; Bao et al., 2014).

96 Because cratonic lithosphere is thicker than surrounding younger lithosphere, a step in

97 lithospheric thickness occurs across the margins of cratons. This has been imaged

98 tomographically in several locations; Figure 2 illustrates three examples. Cratonic lithosphere is

99 generally colder than younger lithosphere, and in tomographic images a craton boundary

100 typically is manifested as a sharp seismic velocity gradient with faster velocities below the craton

101 and lower velocities adjacent to the craton boundary. These tomographic images can be used to

102 understand the geometry of a craton margin. The three examples in Figure 2 (the European

103 Sorgenfrei-Tornquist Zone, the western margin of the Colorado Plateau, and western Canada)

104 show sharp, steep lithospheric steps over short lateral distances, resulting in craton boundaries

105 that vary between sub-vertical and dips larger than 45 degrees. The vertical size of a step may be

$106100 \mathrm{~km}$ or more. For western Canada, this geometry is inferred to have been in place for at least

107 50-100 Ma (Lowe and Ranalli, 1993; Bao et al., 2014); for the Colorado Plateau for 10-20 Ma

108 (van Wijk et al., 2010), and for northern Europe, it may have been in place for 200-300 Ma

109 (Hieronymus et al., 2007). As a result of the steep lithospheric step, there are large lateral

110 thermal gradients across the margins of cratons. In western Canada, the thermal contrast

111 between the mobile belt and craton has long been recognized through surface heat flow and other

112 geophysical observations (Lowe and Ranalli, 1993; Hyndman and Lewis, 1999).

113 Such large thermal gradients will induce edge-driven convection (e.g., King and

114 Anderson, 1998; Shahnas and Pysklywec, 2004; King, 2005; van Wijk et al., 2010; Hardebol et

115 al., 2012). Edge-driven convection is small-scale (upper) mantle convection induced by the

116 lateral variations in temperature (and therefore density). It creates downgoing flow below the 
117 craton and upwelling flow below adjacent thinner lithosphere. The downgoing flow may

118 destabilise cratonic mantle lithosphere when this is weak, dense, and has low viscosity (King and

119 Anderson, 1998; van Wijk et al., 2010), thereby eroding the craton margin. This form of craton

120 destruction has received less scrutiny than craton destruction from below and is therefore the

121 focus of this study.

122 Here, we use simplified numerical models of the lithosphere and upper mantle to address

123 the stability of an abrupt change in lithosphere thickness. Such a step in lithosphere thickness and

124 the accompanying large thermal gradient may suddenly arise when plate tectonic processes affect

125 and deform the mobile belts and younger lithosphere that surround cratonic lithosphere. Once a

126 step is created, craton margins may either undergo erosion or remain stable and resistant to

127 erosion. Our goals are to assess the conditions under which such a step in thickness can be

128 maintained on timescales of 50 to $100 \mathrm{Ma}$ and marginal erosion is limited. This timescale is

129 motivated by the observations from western Canada, which suggest that the Cordillera-Craton

130 transition was created by at least the Eocene (Bao et al., 2014) and perhaps prior to the Late

131 Cretaceous (Lowe and Ranalli, 1993). The numerical models provide insight into the physical

132 conditions needed to explain the seismic images of an abrupt contrast in lithosphere thickness

133 (Figure 2) and provide constraints on the mechanisms of craton destruction through edge-driven

134 instabilities. We further compare and contrast results from our models with earlier studies by

135 Hardebol et al. (2012), Hieronymus et al. (2007) and Wang et al. (2014). The combined insight

136 from these studies and the present study provides a framework for understanding the rheological

137 and density conditions that protect craton margins from erosion while surrounding mobile belts

138 are undergoing deformation. 


\section{2. Numerical models of craton margins}

\section{$141 \quad 2.1$ Model geometry and governing equations}

142 The initial geometry of the numerical models is shown in Figure 3. The two-dimensional

143 models start with the juxtaposition of continental lithospheres with thicknesses of $60 \mathrm{~km}$ and 160

$144 \mathrm{~km}$, and the thermal-mechanical evolution is monitored to determine how the transition in

145 thickness changes with time. The initial transition corresponds to a vertical step in thickness

146 between cratonic lithosphere and younger lithosphere of a mobile belt. This represents an end-

147 member situation, for example following a tectonic event in which one area of continental

148 lithosphere experiences abrupt thinning (e.g., extension of the Basin and Range Province

149 creating a step in lithosphere thickness with the Colorado Plateau (van Wijk et al., 2010) or

150 delamination of Canadian Cordillera lithosphere causing abrupt lithosphere thinning adjacent to

151 the North American craton (Bao et al., 2014)), or through transcurrent plate movement which

152 places a thin lithosphere next to thicker lithosphere (e.g., Stern et al., 2013).

153 The models are $2400 \mathrm{~km}$ wide and $600 \mathrm{~km}$ deep, and the lithospheric step is located in

154 the middle of the model domain. The initial continental crust thickness is $40 \mathrm{~km}$, consisting of a

$15525 \mathrm{~km}$ upper-mid crust and $15 \mathrm{~km}$ lower crust. The thickness and properties of the two crustal

156 layers are uniform across the model. On the left side of the model, the mantle lithosphere is 20

$157 \mathrm{~km}$ thick, giving a total lithosphere thickness of $60 \mathrm{~km}$. This side represents younger lithosphere.

158 On the right side, the mantle lithosphere is $120 \mathrm{~km}$ thick and the total lithosphere thickness is

$159160 \mathrm{~km}$; this side represents older lithosphere. For simplicity, we also refer to the thinner

160 lithosphere as the "mobile belt" and the thicker lithosphere as the "craton" when discussing the

161 models.

162 The finite element code SOPALE is used to model the coupled thermal-mechanical 
163 evolution of the system, subject to the conditions of plane strain and incompressibility (Fullsack,

164 1995). Material deformation is governed by the equations of conservation of mass (volume):

165

$$
\frac{\partial \mathrm{v}_{\mathrm{j}}}{\partial \mathrm{x}_{\mathrm{j}}}=0
$$

166 and conservation of force balance:

$$
\frac{\partial \sigma_{i j}}{\partial x_{i}}+\rho g=0
$$

168 where $\mathrm{x}_{\mathrm{i}, \mathrm{j}}$ are spatial coordinates, $\mathrm{v}_{\mathrm{i}, \mathrm{j}}$ are components of velocity, $\rho$ is density, and $\mathrm{g}$ is (vertical)

169 gravitational acceleration. Repeated indices imply summation and $i, j=1,2$ in the two-

170 dimensional models. The components of the stress tensor are:

$$
\sigma_{i j}=-P \delta_{i j}+\sigma_{i j}^{\prime}=-P \delta_{i j}+2 \eta_{e f f} \dot{\varepsilon}_{i j}
$$

172 where $\mathrm{P}$ is the total pressure, $\sigma^{\prime}{ }_{\mathrm{ij}}$ is the deviatoric stress tensor, $\delta_{\mathrm{ij}}$ is the Kronecker delta ( 1 if

$173 \mathrm{i}=\mathrm{j} ; 0$ if $\mathrm{i} \neq \mathrm{j}$ ), $\eta_{\text {eff }}$ is the effective viscosity, and the strain rate tensor is:

$$
\dot{\varepsilon}_{i j}=\frac{1}{2}\left(\frac{\partial v_{i}}{\partial x_{j}}+\frac{\partial v_{j}}{\partial x_{i}}\right)
$$

The energy balance equation is used to calculate the temperature field:

$$
\rho c_{p}\left(\frac{\partial T_{K}}{\partial t}+v_{i} \frac{\partial T_{K}}{\partial x_{i}}\right)=k \frac{\partial}{\partial x_{i}}\left(\frac{\partial T_{K}}{\partial x_{i}}\right)+A_{T}+\sigma_{i j}^{\prime} \dot{\varepsilon}_{i j}+v_{2} \alpha g T_{K} \rho
$$

177 where $c_{p}$ is specific heat, $T_{K}$ is the absolute temperature, $t$ is time, $k$ is thermal conductivity, $A_{T}$ is

178 volumetric radioactive heat production, and $\alpha$ is the volumetric thermal expansion coefficient.

179 The third term on the right side of equation (5) corresponds to strain heating, in which all

180 dissipated mechanical energy is converted to heat, and the last term is the temperature correction

181 for adiabatic heating for vertical velocity v2. In our models, the thermal and mechanical fields are

182 coupled through the temperature-dependent density and viscous rheology of model materials,

183 and the strain heating term in equation (5).

184 The SOPALE code uses an Arbitrary Eulerian-Lagrangian approach to solve the above 
185 equations, subject to the boundary conditions described below (Fullsack, 1995). The governing

186 equations are solved on an Eulerian finite element mesh that is fixed in space, except that it can

187 stretch vertically to conform to the top model boundary as topography develops. Materials are

188 tracked on a Lagrangian mesh and additional Lagrangian tracer particles. At each time-step, the

189 Lagrangian particles are advected by the model velocity field, and the new distribution is used to

190 update the material properties in the Eulerian mesh. The Eulerian mesh uses element widths of

$19110 \mathrm{~km}$ for the entire domain. Element heights are $2.5 \mathrm{~km}$ in the upper $50 \mathrm{~km}, 5 \mathrm{~km}$ between 50

192 and $400 \mathrm{~km}$ depth, and $10 \mathrm{~km}$ in the lower $200 \mathrm{~km}$ of the model domain. Previous benchmarking

193 tests (e.g., Pysklywec and Beaumont, 2004; Currie et al., 2015) show that this mesh can resolve

194 the growth rates of lithospheric gravitational instabilities to within a $6 \%$ of the expected values.

195

$196 \quad 2.2$ Material properties

197 Table 1 lists the material parameters that are used in the reference model; in subsequent

198 models, the rheology and the density of the craton mantle lithosphere are varied. All materials

199 have a viscous-plastic rheology. Materials follow a pressure-dependent Drucker-Prager yield

200 criterion at shallow depths and high stresses:

201

$$
\mathrm{J}_{2}^{\prime}=\mathrm{c}_{0} \cos \phi_{\mathrm{eff}}+\text { Psin } \phi_{\mathrm{eff}}
$$

202 where $\mathrm{c}_{0}$ is the cohesion, $\phi_{\text {eff }}$ is the effective internal angle of friction, and $\mathrm{J}_{2}{ }_{2}$ is the square root of

203 the second invariant of the deviatoric stress tensor $\left(\mathrm{J}_{2}^{\prime 2}=0.5{\sigma^{\prime}}^{2} \sigma^{\prime}{ }_{\mathrm{ij}}\right)$. Frictional plastic

204 deformation is modelled using an effective viscosity that places the state of stress on yield

205 (Fullsack, 1995; Willett, 1999). At larger depths and lower stresses, deformation is viscous, with

206 an effective viscosity given by:

$$
\eta_{\text {eff }}=f\left(B^{*}\right)\left(\dot{I}_{2}\right)^{(1-n) / n} \exp \left(\frac{E^{*}+P^{*}}{n_{R T}}\right)
$$


208 where $\dot{\mathrm{I}}_{2}$ is the square root of the second invariant of the strain rate tensor $\left(\dot{\mathrm{I}}_{2}{ }^{2}=0.5 \dot{\varepsilon}_{\mathrm{ij}} \dot{\varepsilon}_{\mathrm{ij}}\right), \mathrm{f}$ is a

209 scaling factor, $\mathrm{B}^{*}$ is the pre-exponential factor, $\mathrm{n}$ is the stress exponent, $\mathrm{E}^{*}$ is the activation

210 energy, $\mathrm{V}^{*}$ is the activation volume and $\mathrm{R}$ is the universal gas constant. The four rheological

211 parameters $\left(\mathrm{B}^{*}, \mathrm{n}, \mathrm{E}^{*}\right.$, and $\left.\mathrm{V}^{*}\right)$ are obtained from laboratory studies of deformation of crustal and

212 mantle rocks. The scaling factor (f) is used to linearly scale the effective viscosity up/down

213 relative to the reference laboratory materials. This allows us to vary the material strength to

214 account for variations in material composition relative to the laboratory materials and/or

215 uncertainties in the rheological parameters (see Beaumont et al., 2006 for a discussion). There is

216 significant uncertainty in the application of laboratory-derived deformation parameters to

217 deformation at geological time and space scales. For example, it is necessary to extrapolate the

218 laboratory strain rates over many orders of magnitudes. Bürgmann and Dresen (2008) however

219 show that laboratory-based rheologies are in good agreement with geodetic and field

220 observations of deformation, suggesting that laboratory-derived parameters provide a good

221 description of geological deformation.

222 In our models, we base the material rheologies on several well-established flow laws. The 223 crustal rheology parameters follow those used by Beaumont et al. (2006). In all models, the

224 upper-mid crust rheology is based on a wet quartzite rheology (Gleason and Tullis, 1995), with a

225 scaling factor of $\mathrm{f}=5$ assuming that the crust is more mafic and less hydrated than wet quartzite.

226 The lower crust uses the dry Maryland diabase rheology of Mackwell et al. (1998), with $\mathrm{f}=0.1$ to

227 approximate a more hydrated material. The rheology parameters of the mantle lithosphere and

228 sublithospheric mantle are based on the wet olivine dislocation creep flow law of Hirth and

229 Kohlstedt (2003). In this flow law, the pre-exponential factor $\left(\mathrm{B}^{*}\right)$ in Equation 7 includes a term 230 for water content: 


$$
\left.\mathrm{B}^{*}=\frac{1}{2}\left(\frac{3^{(\mathrm{n}+1) / 2}}{2}\right)^{-1 / \mathrm{n}}\left(\mathrm{A}_{\mathrm{uni}} \mathrm{C}_{\mathrm{OH}}\right)^{\mathrm{r}}\right)^{-1 / n}
$$

232 where $\mathrm{A}_{\text {uni is }}$ is the experimentally-derived constant, $\mathrm{CoH}$ is the water content in $\mathrm{ppm} \mathrm{H} / \mathrm{Si}$, and $\mathrm{r}$ is

233 the water content exponent (Hirth and Kohlstedt, 2003). The first term in brackets converts the

234 rheological parameters from uniaxial laboratory experiments to the tensor invariant state of the

235 numerical models. As a reference, we use a water content of $1000 \mathrm{ppm} \mathrm{H/Si}$, which is

236 comparable to the average mantle water content inferred from mid-ocean ridge studies (Hirth and

237 Kohlstedt, 1996). In the reference model, this rheology is assigned to the sublithospheric mantle

238 and the mantle lithosphere of both continental regions.

239 All materials have a temperature-dependent density:

$$
\rho(T)=\rho_{0}\left(1-\alpha\left(T-T_{0}\right)\right)
$$

241 where $\alpha$ is the volumetric thermal expansion coefficient and $\rho_{0}$ is the reference density at

242 temperature $\mathrm{T}_{0}$. The reference density and temperature for each model material are consistent

243 with expected densities for crust and mantle rocks (e.g., Poudjom Djomani et al., 2001;

244 Beaumont et al., 2006). In the reference model, all mantle materials (mantle lithosphere,

245 sublithospheric mantle) have the same reference density, and there is no compositional density

246 difference between different mantle materials.

\subsection{Initial and boundary conditions}

249 Models are initialised with the material distribution shown in Figure 3. The initial

250 temperature structure is given by one-dimensional conductive geotherms based on the

251 lithosphere thickness at each point in the model (Figure 4a). The base of the lithosphere

252 corresponds to the intersection of the geotherm and a mantle adiabat with potential temperature

$2531300^{\circ} \mathrm{C}$ and adiabatic gradient of $0.4^{\circ} \mathrm{C} / \mathrm{km}$. The geotherms give a Moho temperature of $989^{\circ} \mathrm{C}$ 
254 and $450^{\circ} \mathrm{C}$ for the thin and thick lithosphere, respectively. These are consistent with the Moho

255 temperatures for the Cordillera and craton regions of western Canada (e.g., Lowe and Ranalli,

256 1993; Hyndman and Lewis, 1999; Currie and Hyndman, 2006; Hyndman et al., 2009). The

257 sublithospheric mantle initially has an adiabatic thermal structure. We do not explicitly model

258 convection in the sublithospheric mantle prior to the start of the models, i.e., to generate the

259 adiabatic temperatures. However, as the models run, lateral density variations induce thermal

260 convection in the sublithospheric mantle.

261 Boundary conditions are shown in Figure 3. The upper boundary of the model is a stress-

262 free surface with $\mathrm{T}=0^{\circ} \mathrm{C}$, and thus, topography can develop dynamically during model evolution.

263 Topography is not part of our discussion below; we focus here on the stability of the boundary

264 between cratonic and younger lithosphere. The side boundaries are insulating (no horizontal heat

265 flow) and no-slip. The bottom boundary is a no-slip boundary with $\mathrm{T}=1540^{\circ} \mathrm{C}$. Tests show that

266 the use of free-slip conditions on the sides and bottom does not affect the overall model

267 behaviour, as these boundaries are far from the area of interest (the lithosphere step).

268 The model runs consist of two stages. The models are run for a short time to bring the

269 two lithospheres into isostatic equilibrium. In this stage, the left-hand boundary of the model has

270 a no-slip boundary condition and the right-hand boundary has a free-slip condition. This allows

271 the craton lithosphere to move vertically and in most cases, the craton subsides relative to the

272 thinner lithosphere. After isostatic equilibrium is established, both side boundaries are set to be

273 no-slip boundaries, and the models are run to 100 Ma to assess the behaviour of the lithosphere

274 step.

275

276 3. Reference model 
In the reference model, the only difference between the thick lithosphere (craton) and the

278 adjacent thin lithosphere (mobile belt) is the initial temperature structure (Figure 4a); the craton

279 mantle lithosphere is an average of $\sim 250^{\circ} \mathrm{C}$ cooler than the mobile belt. Both mantle lithospheres

280 and the sublithospheric mantle have the same rheology and density properties (Table 1). Owing

281 to the cooler temperatures within the craton lithosphere, its density is greater than that of the

282 sublithospheric mantle. The thermal density contrast increases from $0 \mathrm{~kg} / \mathrm{m}^{3}$ at the base of the

283 craton lithosphere to over $90 \mathrm{~kg} / \mathrm{m}^{3}$ at the Moho (Figure $4 \mathrm{~b}$ ).

284 The evolution of this model is shown in Figure 5. At the start of the model run, the step

285 change in lithosphere thickness induces edge-driven convection at the margin of the craton

286 lithosphere. The craton lithosphere has a downward velocity owing to its cool temperature and

287 high density; this is coupled with an upwelling below the adjacent thin lithosphere. By $10 \mathrm{Ma}$,

288 the corner of the craton is gravitationally removed as a narrow $(\sim 20 \mathrm{~km})$ drip. Over time,

289 additional gravitational instabilities are induced at the base of both the thin and craton

290 lithosphere, resulting in time-dependent small-scale downwellings of the cool lower lithosphere.

291 The craton material then circulates within the sublithospheric mantle (blue material in Figure 5).

292 After $100 \mathrm{Ma}$, convection has removed over $40 \mathrm{~km}$ of the deep craton lithosphere. In addition,

293 the edge of the craton has been eroded, creating a transition from thin to thick lithosphere over a

294 horizontal distance of 200-300 km.

296 4. Effect of craton properties on craton margin stability

2974.1 Origin of density and rheology variations of cratons

298 The main objective of our study is to determine the conditions under which a steep (i.e.,

$299>45^{\circ}$ ) lateral change in lithosphere thickness at the craton boundary can be maintained over 
300 timescales of at least 50-100 Ma following tectonic rejuvenation (thinning) of adjacent

301 lithosphere; this would point to a stable craton margin. The sharp boundary between cratonic and

302 younger lithosphere (Figure 2) would be erased by edge-driven convection if cratonic mantle

303 lithosphere is easily removed by this process. Gravitational stability of mantle lithosphere

304 depends on both its rheology and density structure (e.g., Houseman and Molnar, 1997; Conrad

305 and Molnar, 1999). In the reference model (Figure 5), the cooler craton lithosphere temperatures

306 result in a mantle lithosphere that is more dense than the sublithospheric mantle (Figure 4a) and

307 is gravitationally unstable, while its rheology is weak enough so that the craton corner may

308 deform and drip. This leads to a smoothing of the lithosphere step (Figure 5). This is an example

309 of an unstable craton margin where the craton is eroded from its sides. Below, the rheology and

310 density of the craton mantle lithosphere are varied to understand the conditions that keep the

311 craton margin intact.

312 An important control on the strength of the mantle is its water content. Here, we focus on 313 the effect of water on olivine strength as olivine is the most abundant mineral in the upper mantle

314 and as it is believed to be the weakest, its rheology should control the overall strength of mantle

315 rocks (Karato, 2008). As water is added to olivine, it becomes weaker (e.g., Karato and Wu,

316 1993; Hirth and Kohstedt, 1996; 2003; Karato, 2008). Figure 4c shows the variation in olivine

317 viscosity for changes in water content (equations 7 and 8), using the craton geotherm from our

318 models. Relative to our reference value of $\mathrm{COH}=1000 \mathrm{H} / 10^{6} \mathrm{Si}$ (damp olivine), water contents of

319100 and $10 \mathrm{H} / 10^{6} \mathrm{Si}$ result in a viscosity increase by a factor of 2.2 and 4.8 , respectively (Figure

3204 d). Also shown in Figure 4c is the calculated viscosity for a water-saturated olivine based on the

321 Hirth and Kohlstedt (2003) wet olivine flow law and the olivine water-saturation curve of

322 Hirschmann et al. (2005) (Figure 4a). This predicts that the viscosity of water- saturated olivine 
323 is $0.3-0.6$ that of the reference damp olivine (Figure 4d). Hirth and Kohlstedt (2003) provide

324 rheological parameters for dry olivine $\left(A_{u n i}=1.1 \times 10^{-16} \mathrm{~Pa}^{-3.5} \mathrm{~s}^{-1} ; \mathrm{n}=3.5 ; \mathrm{E}^{*}=530 \mathrm{~kJ} / \mathrm{mol}, \mathrm{V}^{*}=15\right.$

$325 \mathrm{~cm}^{3} / \mathrm{mol}$ ). A comparison of the viscosity from this flow law and that of the reference damp

326 olivine (Figure 4c) shows that the dry olivine is 6 to 19 times stronger (Figure 4d). In the models

327 below, we vary the rheology of the craton mantle lithosphere by scaling its effective viscosity

328 relative to the reference damp olivine rheology. We test scaling factors of $\mathrm{f}=0.5$ (i.e., half the

329 strength) to $\mathrm{f}=50$, which covers the predicted strengths for all water contents from dry to water-

330 saturated.

331 One hypothesis for the longevity and thickness of cratonic mantle is that it is chemically

332 depleted and therefore its density is lower than that of the underlying mantle (e.g., King, 2005

333 and Lee et al., 2011 for overviews). Poudjom Djomani et al. (2001) suggest that Archaean

334 lithosphere may be as much as $80 \mathrm{~kg} / \mathrm{m}^{3}$ less dense than primitive mantle (at the same

335 temperature) and that Proterozoic mantle may be up to $50 \mathrm{~kg} / \mathrm{m}^{3}$ less dense. We assume a

336 constant reference density throughout the cratonic mantle lithosphere and we investigate

337 densities that are up to $80 \mathrm{~kg} / \mathrm{m}^{3}$ less than that of the surrounding mantle (at the same

338 temperature). This difference in density is also called the compositional density difference $(\Delta \rho)$.

339 We also consider models in which the reference density of craton mantle lithosphere is 20 and 40

$340 \mathrm{~kg} / \mathrm{m}^{3}$ greater than that of the surrounding mantle. It is suggested that some craton lithosphere

341 may have formed through stacking of subducting oceanic plates (e.g., Lee et al., 2011 and

342 references therein). In this case, the craton lithosphere may contain small regions of eclogitised

343 crust, which can have a density greater than that of mantle. Craton mantle with an excess density

344 of $20 \mathrm{~kg} / \mathrm{m}^{3}$ or $40 \mathrm{~kg} / \mathrm{m}^{3}$ corresponds to an eclogite content of $\sim 7 \%$ or $\sim 13 \%$, respectively, based

345 on an eclogite density of $3550 \mathrm{~kg} / \mathrm{m}^{3}$ (Austrheim et al., 1997). 


\section{$347 \quad 4.2$ Model results}

348 Figure 6 shows a summary of the model results for different combinations of craton

349 compositional density difference and rheology. Each model was run for $100 \mathrm{Ma}$ and the

350 behaviour of the lithospheric step was monitored. Models are grouped according to the dynamics

351 of the step and its geometry at 50 and $100 \mathrm{Ma}$. To quantitatively describe the geometry, we

352 measure the dip angle of both the $1200^{\circ} \mathrm{C}$ contour and the material boundary between lithosphere

353 and sublithospheric mantle at depths of 80 to $140 \mathrm{~km}$. This is based on the idea that seismic

354 tomography velocities (e.g., Figure 2) are most sensitive to temperature in the mantle, with

355 composition being a secondary effect, except in cases where the craton is strongly chemically

356 distinct (e.g., Goes et al., 2000). For all models, these two measures yield similar angles for the

357 transition from thin to thick lithosphere over the duration of the model run. Below, we describe

358 the results of selected models that demonstrate the range of behaviours.

359 Figure 7 shows the effect of variations in craton compositional density for two models in

360 which the craton mantle lithosphere is 10 times stronger than the reference model $(\mathrm{f}=10)$. If the

361 craton lithosphere has the same reference density as the underlying mantle (Figure 7a), the step

362 in lithosphere thickness is gravitationally unstable, but the instability is smaller and slower than

363 in the reference model. By $50 \mathrm{Ma}$, the lithosphere step still has a relatively steep slope $\left(>45^{\circ}\right)$.

364 After $100 \mathrm{Ma}$, ongoing erosion gradually reduces the slope to less than $45^{\circ}$, but the craton

365 inboard of the margin has not been thinned. If the craton compositional density is $40 \mathrm{~kg} / \mathrm{m}^{3}$

366 greater than that of mantle (Figure 7b), the craton margin is more unstable, which leads to a more

367 rapid erosion of the lithosphere step. These models demonstrate that a high craton viscosity

368 promotes stabilization of the lithosphere step. However, this is not sufficient to maintain a 
369 lithosphere step angle $>45^{\circ}$ after $100 \mathrm{Ma}$, as observed for example in the Sorgenfrei-Tornquist

370 tomographic transect (Figure 2a).

371 An alternate way to stabilise the craton is to reduce its mantle lithosphere density. Models

372 with a compositionally buoyant craton $\left(40 \mathrm{~kg} / \mathrm{m}^{3}\right.$ less dense than sublithospheric mantle) are

373 presented in Figure 8. With this compositional buoyancy, the lower $\sim 55 \mathrm{~km}$ of the craton mantle

374 lithosphere is less dense than the sublithospheric mantle, even though it is cooler. Figure 8a

375 shows a model in which the craton lithosphere has the reference rheology (damp olivine). The

376 step in lithosphere thickness is gravitationally unstable and the craton lithosphere is weak enough

377 to undergo viscous flow. Instead of downwelling, lowermost craton mantle lithosphere viscously

378 spreads and flows laterally, owing to its positive buoyancy. It then upwells and underplates the

379 adjacent thin lithosphere. Over $100 \mathrm{Ma}$, the craton lithosphere has flowed more than $200 \mathrm{~km}$

380 outboard, leading to thinning of the craton near its original margin and a more gradual transition

$381\left(<30^{\circ}\right.$ dip) between thin and thick lithosphere. The outward flow of buoyant craton lithosphere is

382 reduced by increasing the lithosphere strength. If the strength is increased by an order of

383 magnitude (Figure 8b), there is very little removal of the edge of the craton lithosphere and the

384 lithosphere step remains steep over the 100 Ma model run.

385 Figure 9 shows the surface heat flow for the two models in Figure 8, as well as the

386 reference model (Figure 5). These three models exhibit the range of behaviours observed in our

387 models. In all models, the mobile belt area has relatively high heat flow $\left(60-70 \mathrm{~mW} / \mathrm{m}^{2}\right)$ and the

388 craton block heat flow is $40-50 \mathrm{~mW} / \mathrm{m}^{2}$. However, the transition from high to low heat flow

389 varies depending on the dynamics of the step. With a stable step (model in Figure 8b), the heat

390 flow transition occurs over a lateral distance of $\sim 150 \mathrm{~km}$ and does not change significantly

391 during the model run. If the step destabilizes through downwelling (model in Figure 5), the 
392 transition migrates into the craton and becomes slightly broader over time. If the step that

393 destabilizes through lateral spreading (model in Figure 8a), the transition migrates into the

394 mobile belt and is even broader $(>300 \mathrm{~km})$; the effects become most pronounced late in the

395 model run, as the mobile belt crust is cooled by the underplated cratonic lithosphere. Thus, the

396 location of the heat flow transition relative to the geological boundary of the craton at the surface

397 may be diagnostic of the deeper dynamics of the craton margin.

\section{$399 \quad 4.3$ Regime diagram}

400 The behaviour of the craton margin for the range of craton strengths and densities that we

401 have tested is summarised in the regime diagram in Figure 6. In models where the craton

402 compositional density is more than $\sim 30 \mathrm{~kg} / \mathrm{m}^{3}$ less than that of underlying mantle, the edge of the

403 craton undergoes destabilization through lateral flow (as in Figure 8a); at higher densities, the

404 lithosphere step is eroded through downwellings. The lateral flow is driven by the compositional

405 buoyancy of the mantle lithosphere, which makes it less dense that the sublithospheric mantle

406 despite its lower temperatures. We have tested models in which the material densities do not

407 depend on temperature (a thermal expansion co-efficient of $0 \mathrm{~K}^{-1}$ ). In models where the cratonic

408 mantle density is even slightly less than that of the sublithospheric mantle, the cratonic mantle

409 spreads laterally, as it is compositionally buoyant. With no density difference, the mantle

410 materials are stationary and cratonic mantle is stable.

411 The behaviour of the edge of the craton lithosphere depends on: 1) the gravitational

412 buoyancy forces which act to destabilise the step, and 2) the viscous strength of the cratonic

413 mantle, which acts to resist destabilisation. To maintain a steep $\left(>45^{\circ}\right)$ step for over $100 \mathrm{Ma}$, the

414 craton lithosphere must be relatively strong. For a craton density that is equal or greater than that 
415 of mantle or that is strongly depleted $\left(>60 \mathrm{~kg} / \mathrm{m}^{3}\right.$ less dense than mantle), the craton viscosity

416 must be more than an order of magnitude higher than that of damp olivine (at the same

417 temperature); this is greater than the strength of dry olivine. The required strength is reduced if

418 the craton density is $20-60 \mathrm{~kg} / \mathrm{m}^{3}$ less than that of mantle. The compositional positive buoyancy

419 is partially offset by the negative buoyancy from the cool craton temperatures, and therefore the

420 overall gravitational instability of the cratonic mantle lithosphere is reduced and a weaker

421 rheology can remain stable. For a craton with a compositional density that is $40 \mathrm{~kg} / \mathrm{m}^{3}$ less dense

422 than mantle, the craton margin can be preserved if its strength is a factor of 3-4 times greater

423 than that of damp olivine.

424

$425 \quad 4.4$ Effect of a dry olivine (strong) rheology for craton mantle

426 We have also tested models with the rheological parameters for dry olivine from Hirth

427 and Kohlstedt (2003) (Figure 4c). At depths greater than $\sim 100 \mathrm{~km}$ in craton lithosphere, dry

428 olivine is 6-8 times stronger than the reference damp olivine (Figure 4d). At shallower depths,

429 dry olivine is even stronger. This is primarily because its activation energy $\left(E^{*}\right)$ is larger than

430 that of damp olivine, resulting in a greater temperature-dependence. Figure 10 shows the results

431 of models in which the craton compositional density is varied. When the craton has the same

432 compositional density as the underlying mantle (Figure 10a), the lithospheric step is

433 gravitationally unstable. It is gradually eroded through small-scale downwellings, and after 50

$434 \mathrm{Ma}$, the step has an angle less than $45^{\circ}$. If the craton composition density is $40 \mathrm{~kg} / \mathrm{m}^{3}$ less than

435 mantle (Figure 10b), the lower part of the craton is buoyant and tends to upwell. However, the

436 dry rheology prevents significant deformation of the craton margin, and a steep lithosphere step

437 is maintained over $100 \mathrm{Ma}$. After an initial period of lateral upwelling (first $50 \mathrm{Ma}$ ), the step 
438 appears to become steeper as counter-clockwise edge-driven convection adjacent to the step

439 "pushes" the craton lithosphere back toward the margin. A craton with a lower compositional

440 buoyancy $\left(60 \mathrm{~kg} / \mathrm{m}^{3}\right.$ less dense than mantle) is more unstable (Figure 10c). It flows outward up

441 to $\sim 100 \mathrm{~km}$ from the original craton margin and buoyantly underplates the mobile belt

442 lithosphere. This creates a low-angle transition from thin to thick lithosphere.

443 The results of these three models are consistent with the behaviour of our models in

444 which the damp olivine rheology was scaled upward by a factor of 5-10 (Figure 6). For this

445 strength, a steep lithosphere step can only be maintained over $100 \mathrm{Ma}$ if the craton lithosphere

446 has a moderately low density (compositional density $20-40 \mathrm{~kg} / \mathrm{m}^{3}$ less than mantle). At higher

447 densities, the craton margin is eroded through downwellings; at lower densities, the margin

448 spreads outward and the cratonic mantle underplates the adjacent lithosphere.

\section{$450 \quad 4.5$ Effect of mantle wind on craton margin stability}

451 Our models are designed to examine the stability of a craton margin within $100 \mathrm{Ma}$ of

452 tectonic deformation of a mobile belt, and therefore we do not explicitly include a convecting

453 sublithospheric mantle (c.f., Wang et al., 2014). However, a large-scale horizontal mantle flow

454 (mantle wind) may affect the predicted conditions required to maintain a steep step (Figure 6).

455 To test this, we have run several models with a $2 \mathrm{~cm} / \mathrm{yr}$ horizontal flow in the sublithospheric

456 mantle. Figure 11 shows models in which the craton lithosphere has a compositional density 40

$457 \mathrm{~kg} / \mathrm{m}^{3}$ less than the mantle and a rheology that is 5 times stronger than the reference damp

458 olivine. With no mantle wind, the craton margin maintains an angle $>45^{\circ}$ over the 100 Ma model

459 evolution (Figure 11b). 
In Figure 11a, the $2 \mathrm{~cm} / \mathrm{yr}$ mantle wind flows to the left, from the craton toward the

461 mobile belt. This causes a slight leftward viscous shearing of the deep craton lithosphere. As the

462 mantle flow passes below the corner of the craton, a low pressure is created in the shallow

463 sublithospheric mantle next to the craton and counterclockwise flow is induced in this area.

464 This results in a slight steepening of the craton margin, compared to the model with no mantle

465 wind. However, the difference between the models are relatively small and we conclude that a 2

$466 \mathrm{~cm} / \mathrm{yr}$ mantle wind directed toward the mobile belt has little effect on the boundary between the

467 "steep" and "shallow" margins in Figure 6.

468 In contrast, a craton-ward mantle wind results in a noticeable decrease in the angle of the

469 step (Figure 11c). The deep craton lithosphere near the margin is viscously sheared by mantle

470 flow and carried toward the craton. This results in a thickening of the craton lithosphere by $\sim 20$

$471 \mathrm{~km}$ near the boundary of the craton, as the buoyant lithosphere accumulates here. In models

472 where the mantle lithosphere is more dense than mantle (not shown), the lithosphere is

473 gravitationally removed, causing a thinning of the craton edge and a further decrease in the angle

474 of the lithosphere step. For a mantle wind in this direction, the critical strength needed to

475 maintain a steep step may shift to a slightly stronger rheology (Figure 6), especially for cases

476 where the craton mantle lithosphere has a compositional density greater than that of the

477 underlying mantle.

\section{$479 \quad 4.6$ Effect of a thicker craton lithosphere}

480 The above models address the stability of the edge of a 160-km thick craton. We have

481 tested additional models that have a craton thickness of $260 \mathrm{~km}$, resulting in a $200 \mathrm{~km}$ step in

482 thickness at the craton margin. Figure 12 shows two models with a craton mantle lithosphere 
483 that follows a dry olivine flow law (Hirth and Kohlstedt, 2003). If there is no compositional

484 density difference between the craton and sublithospheric mantles (Figure 12a), edge driven

485 convection results in some removal of the craton mantle lithosphere. This primarily affects the

486 lithosphere below $\sim 180 \mathrm{~km}$ depth. The shallower lithosphere remains stable, owing to its cool

487 temperatures and thus high viscosity. Thus, a steeper thickness transition at the craton margin

488 can be maintained over $100 \mathrm{Ma}$ than in a comparable model with a thinner lithosphere (Figure

489 10a).

490 Figure $12 \mathrm{~b}$ shows a model in which the craton mantle lithosphere is $40 \mathrm{~kg} / \mathrm{m}^{3}$ less dense

491 than the sublithospheric mantle. The lower $20-30 \mathrm{~km}$ of the craton flows laterally and

492 underplates the mobile belt; more craton material is displaced than in a similar model with a

493 thinner lithosphere (Figure 10b). The difference in behaviour is due to the differing thermal

494 structures. With a thicker lithosphere, a greater amount of the deep lithosphere is at temperatures

495 greater than $1000-1100^{\circ} \mathrm{C}$, and thus it has both a low density and relatively low strength. As a

496 result, the craton step is smoothed more quickly when the lithosphere thickness is greater.

497 Overall, a thick craton lithosphere with a relatively low compositional buoyancy $(0-20$

$498 \mathrm{~kg} / \mathrm{m}^{3}$ less dense than sublithospheric mantle) is more stable due to cooler temperatures and

499 higher viscosities. Therefore, the strengths in Figure 6 are maximum values. A greater

500 compositional density difference between the craton and sublithospheric mantle decreases the

501 stability of the craton, and therefore it may be more difficult to maintain a steep margin.

\section{5. Discussion: what controls craton margin stability?}

504 Previous geodynamic modeling studies (e.g., Doin et al., 1997; Shapiro et al., 1999; King,

5052005 and references therein; Lenardic et al., 2003; Sleep, 2003; Wang et al., 2014) primarily 
506 addressed the preservation of wide areas of thick $(>200 \mathrm{~km})$ cratonic lithosphere above a

507 convecting mantle. They commonly conclude that thick, cool craton lithosphere is prone to

508 gravitational thinning if it has the same composition as the underlying mantle; the high

509 viscosities associated with cool craton temperatures are insufficient to stabilise the lithosphere.

510 The main factor that can allow thick craton lithosphere to be maintained is a rheologically strong

511 lithosphere. In successful models of craton preservation, the cratonic mantle is 10 to $>100$ times

512 more viscous than the convecting mantle (at the same temperature, pressure and strain rate

513 conditions) (e.g., Lenardic et al., 2003; Sleep, 2003; Wang et al., 2014). Moderate chemical

514 buoyancy of cratonic mantle lithosphere aids in its preservation, but on its own, buoyancy does

515 not ensure craton stability (e.g., Lenardic et al., 2003; King, 2005). Wang et al. (2014) show that

516 even with a buoyant mantle lithosphere, cratons must be a factor of 3 more viscous than

517 convecting mantle (at the same conditions) in order to remain intact. A strong and buoyant

518 cratonic mantle lithosphere is typically attributed to dry and chemically depleted conditions. This

519 composition is consistent with xenolith studies of cratonic composition (e.g., Lee et al., 2001;

520 Poudjom Djomani et al., 2001; Lee et al., 2011).

$521 \quad$ How are the margins of cratonic lithosphere preserved? The sparse seismic studies that

522 cross craton margins show that these boundaries correspond to a transition from relatively high

523 shallow mantle velocities below the craton to lower velocities below the adjacent lithosphere,

524 indicating a change in lithosphere thickness (Figure 2). In several places, such as northern

525 Europe (e.g., Goes et al., 2000; Hieronymus et al., 2007) and western Canada (e.g., Goes and van

526 der Lee, 2002; Bao et al., 2014; Y.J. Gu, personal communication, 2015), the craton margin

527 corresponds to a relatively steep $\left(>45^{\circ}\right)$ gradient in lithosphere thickness; we used this gradient to

528 discriminate between preserved and unstable craton margins in our model analyses. The main 
529 result from our models is that the thicker craton lithosphere must have a distinct rheology (and

530 possibly density) relative to the surrounding mantle in order to maintain a steep transition over

$53150-100 \mathrm{Ma}$. Without a difference in properties, the cool craton lithosphere is eroded by edge-

532 induced convection and its own gravitational instability. For all densities that we have tested, the

533 craton mantle lithosphere viscosity must be significantly stronger than the reference rheology of

534 damp olivine (Figure 6). Strengthening by more than a factor of 10 is required if the cratonic

535 mantle is either compositionally dense $\left(\Delta \rho \geq 0 \mathrm{~kg} / \mathrm{m}^{3}\right)$ or highly buoyant $\left(\Delta \rho<-40 \mathrm{~kg} / \mathrm{m}^{3}\right)$. For a

536 moderate compositional buoyancy, the required strength is slightly lower, as the compositional

537 buoyancy offsets some of the negative thermal buoyancy of the cool, thick region. If a dry

538 olivine rheology is an upper limit on the strength of cratonic mantle, our models predict that a

539 steep gradient in lithosphere thickness can be preserved only if the craton mantle is

540 approximately 20 to $40 \mathrm{~kg} / \mathrm{m}^{3}$ less dense than typical mantle.

541 The overall behaviour of our models is similar to that seen in previous modeling studies

542 that include a lateral change in lithosphere thickness. In Figures 4e and 4f, we show for

543 comparison the viscosity flow laws in three studies (Hieronymus et al., 2007; Hardebol et al.,

544 2012; and Wang et al., 2014) plotted for the conditions in our models. We note however, that the

545 original studies have different model properties (e.g., lithosphere thicknesses, thermal gradients,

546 etc.), as mentioned hereafter. Hieronymus et al. (2007) address the stability of a lithosphere step

547 at the Sorgenfrei-Tornquist Zone in northern Europe (Figure 2a). Their reference (weak)

548 rheology is somewhat weaker than our reference, and they conclude that strengthening by a

549 factor of 50 is required in order to maintain a lithosphere step that agrees with seismological

550 observations; they do not consider variations in density. This magnitude of strengthening is

551 consistent with that predicted by our models for cratons with $\Delta \rho=0 \mathrm{~kg} / \mathrm{m}^{3}$ (Figure 6). 
Hardebol et al. (2012) developed numerical models to address the mantle dynamics at the

553 transition in lithosphere thickness in western Canada (Figure 2c). They find that the thick craton

554 lithosphere is readily eroded with a weak wet olivine rheology, but it can be maintained for 100

555 Ma if the craton has a dry olivine rheology (Hirth and Kohlstedt, 1996); they also do not consider

556 variations in craton density. Hardebol et al. (2012) do not include an activation volume in the

557 rheological formulation (Equation 7) and thus their dry olivine rheology is only slightly stronger

558 than our reference damp olivine rheology (Figure 4f). In our models, we find that a much

559 stronger rheology is needed to maintain the change in lithosphere thickness. A possible reason

560 for the different results between their and our models is that our models use a vertical step in

561 lithosphere thickness whereas Hardebol et al. (2012) implement a $60 \mathrm{~km}$ or $100 \mathrm{~km}$ change in

562 thickness over a horizontal distance of $250 \mathrm{~km}$. With the more gradual lateral gradient, the vigor

563 of edge-driven convection is reduced, which may allow for a greater range of stability than we

564 find. Further, the craton lithosphere in their models is somewhat cooler than in our models,

565 which results in a higher viscosity that may help stabilise the craton.

$566 \quad$ Finally, Figure $4 \mathrm{f}$ shows the reference rheology used by Wang et al. (2014) in their study

567 of craton stability over 2 Gyr, which is a factor of 3-4 stronger than our reference damp olivine

568 rheology. Their models show that cratonic lithosphere that is 3-10 times stronger than this (i.e.,

569 12-40 times stronger than our reference rheology) can remain stable. To preserve a stable craton,

570 the craton strength does not have to be this high if the craton has some compositional buoyancy;

571 Wang et al. (2014) consider a two-layer craton lithosphere with a boundary at $144 \mathrm{~km}$ depth and

572 chemical buoyancy of $70 \mathrm{~kg} / \mathrm{m}^{3}$ and $42 \mathrm{~kg} / \mathrm{m}^{3}$ in the upper and lower layers, respectively. Thus,

573 their overall conclusions are similar to what we find in our study. This suggests that the factors

574 that promote the longevity of thick cratonic lithosphere also enable its margins to be preserved as 
575 areas of steep gradients in thickness. In other words, a thick, strong and buoyant craton should be

576 characterised by steep changes in lithosphere thickness at its margins.

577 Our models also show that a lithospheric step is readily eroded if the craton mantle is

578 weaker than dry olivine for most of the densities we have tested (Figure 6). If the craton density

579 is similar or greater than that of the surrounding mantle, destabilization occurs through

580 downwellings that progressively erode the craton inward, resulting in the gradual decrease in the

581 relief on the base of the lithosphere at the craton margin. This result is consistent with seismic

582 observations and magmatic data, and surface topography at places such as the Rio Grande Rift

583 (van Wijk et al., 2008), Colorado Plateau (van Wijk et al., 2010; Figure 2b), and the North Island

584 of New Zealand (Stern et al., 2013). In these places, it is inferred that continental lithosphere is

585 actively thinned through convective instabilities induced by the lateral variation in lithosphere

586 thickness.

587 If the craton mantle lithosphere is both weak and highly buoyant $\left(\Delta \rho<-40 \mathrm{~kg} / \mathrm{m}^{3}\right)$, we

588 find that a step in lithospheric thickness destabilises through lateral gravitational spreading, such

589 that buoyant craton lithosphere underplates the adjacent mobile belt lithosphere. This behaviour

590 is also seen in the numerical models of Wang et al. (2014), as well as models of lithosphere

591 dynamics at passive margins (e.g., Huismans and Beaumont, 2011; Beaumont and Ings, 2012;

592 Armitage et al., 2012). As noted by Beaumont and Ings (2012), cratonic lithosphere is generally

593 inferred to be both chemically buoyant and anhydrous (and therefore strong), owing to partial

594 melting and chemical depletion during craton formation. In order for lithosphere to be weak

595 enough to flow laterally, either the initial depletion event must not have fully dehydrated the

596 lithosphere, or the lithosphere experienced later refertilisation or metasomatism that resulted in

597 weakening but no significant density increase. At passive margins, lateral flow of buoyant craton 
598 lithosphere has been invoked to explain exhumation of continental mantle lithosphere, magma

599 and xenolith geochemistry and temporal changes in topography (Huismans and Beaumont, 2011;

600 Beaumont and Ings, 2012; Armitage et al., 2012). We are not aware of observational evidence of

601 this process at the boundary of cratonic lithosphere in continental interiors (K. Condie, personal

602 communication, 2015), but a more thorough examination of geophysical and geological data is

603 needed. Kaban et al. (2015) propose that the deep root beneath the Superior craton (Figure 1) has

604 shifted laterally, away from its original position, by basal drag resulting from mantle flow.

605 Underplating of buoyant craton mantle lithosphere as predicted by some of our models would be 606 an alternative mechanism for root displacement.

607 In our study, we have used simplified numerical models to demonstrate the dynamics that 608 may occur where there is a step in lithosphere thickness at a craton margin. Through a systematic 609 variation in the rheology and density of the cratonic lithosphere, our models constrain the 610 conditions that may permit a steep gradient in lithosphere thickness to be maintained (Figure 6).

611 In doing this, we have made several assumptions. For example, the majority of our models

612 consider a $100 \mathrm{~km}$ vertical step between the mobile belt and craton lithosphere, with a $160 \mathrm{~km}$

613 thickness for the craton. A thicker craton may be more stable, unless its compositional density is

614 significantly different than that of the sublithospheric mantle (Section 4.6). Similarly, as

615 discussed above, a more gradual step in lithosphere thickness may lead to a greater degree of 616 craton stability. Furthermore, our models do not include mantle convection or plate tectonic

617 processes. A horizontal mantle flow of $2 \mathrm{~cm} / \mathrm{yr}$ does not significantly affect the model behaviour 618 over a timescale of $100 \mathrm{Ma}$, especially if the mantle flow is directed toward the mobile belt

619 (Figure 11). However, larger flow velocities or interactions between the craton margins and plate 620 margin processes (e.g., a subducting plate) may have a greater effect. We have also not 
621 considered the effect of vertical layering within the craton mantle lithosphere or variations in

622 crustal strength. These may introduce weak interfaces to the lithosphere, which may promote

623 destabilisation and should be examined in future studies. Finally, our models address stability on

624 a timescale of $100 \mathrm{Ma}$. At longer timescales, the effects of conductive heating and continued

625 shearing from mantle flow may start to erode the step. In this case, the preservation of the step

626 may also depend on the structure of the adjacent lithosphere and the degree to which it shields

627 the craton boundary from mantle stresses (e.g., Lenardic et al., 2000).

628

629 6. Conclusions

630 Seismic tomography data show that the boundary between cratonic and younger

631 continental lithosphere corresponds with a sharp gradient in upper mantle seismic velocities (e.g.

632 Figure 2). In several places, craton margins corresponds to a steep $\left(>45^{\circ}\right)$ gradient in lithosphere

633 thickness from $>100 \mathrm{~km}$ below the craton to $<100 \mathrm{~km}$ below the adjacent continent. We have

634 used numerical models to understand how variations in the rheology and density of the craton

635 lithosphere affect the geometry of the craton margin. We conclude the following:

636 - in accordance with earlier modeling studies of craton longevity, the rheology of the

637 cratonic mantle lithosphere is the primary control on its stability. Cratonic mantle must

638 have a stronger intrinsic rheology than the underlying mantle. The compositional

639 buoyancy of cratonic lithosphere provides a secondary control, but even a buoyant craton

640 requires some rheological strengthening to remain stable.

641 - if the craton mantle rheology follows existing olivine flow laws, a steep gradient in

642 lithosphere thickness at the craton margin can only be maintained if the craton is dry 
643

644 dense than underlying mantle).

645 if the lithosphere is denser than this, a lithospheric step is eroded through downwellings

646 that remove the edge of the craton margin. Conversely, if the lithosphere is more buoyant,

647 it destabilises through laterally spreading, resulting in underplating of cratonic

648 lithosphere below the adjacent lithosphere.

650 There are only a few tools available to study the dynamics of cratons over millions to

651 billions of years. Xenoliths, magmatism and surface geology provide a detailed, but incomplete,

652 picture of select regions. Most geophysical observations (e.g. seismic tomography) provide

653 snapshots of present-day structure and therefore must be carefully interpreted to gain insight into

654 dynamic processes. Numerical models, such as those presented here, provide an experimental

655 framework for studying the temporal evolution of the lithosphere-upper mantle system. However,

656 the models are necessarily simplified relative to the real Earth and use material properties that

657 are often not well-constrained. Nevertheless, numerical models are useful because they provide

658 insight into how different parts of the system may dynamically interact. They also provide

659 testable predictions for how these dynamics may be recognised in surface geological and

660 geophysical observations. For example, the models in this study predict that regions with a steep

661 lithosphere gradient at the craton margin (e.g., western Canada, Sorgenfrei-Tornquist zone) have

662 a dry and chemically depleted craton mantle lithosphere. This prediction should quantitatively be

663 tested against geophysical observations such as seismic tomography (e.g., Figure 2), gravity and

664 magnetotellurics, as well as geochemical studies of craton mantle lithosphere composition. 
Acknowledgements. We thank Kent Condie, Yu Jeffrey Gu, and Roy Hyndman for discussions, Tim Stern and Scott King for constructive reviews, and Vincent Strak for his editorial handling of this manuscript. Numerical models use the SOPALE code, developed by Philippe Fullsack, with additional modifications by Bonny Lee and Douglas Guptill, under the direction of Christopher Beaumont at Dalhousie University (Halifax, NS). Numerical models were run using computational resources from WestGrid (Compute Canada). This research was funded by the Natural Sciences and Engineering Research Council of Canada (NSERC), and National Science Foundation grant EAR-1015250.

\section{References}

Armitage, J.J., Jaupart, C., Fourel, L., Allen, P.A., 2012. The instability of continental passive margins and its effect on continental topography and heat flow. Journal of Geophysical Research 118, 1817-1836.

Artemieva, I.M., Mooney, W., 2001. Thermal thickness and evolution of Precambrian lithosphere: a global study. Journal of Geophysical Research 106, 16,387-16,414.

Audet, P., Bürgmann, R., 2011. Dominant role of tectonic inheritance in supercontinent cycles. Nature Geoscience 4, 184-187, doi:10.1038/ngeo1080.

Austrheim, H., Erambert, M., Engvik, A.K., 1997. Processing of crust in the root of the Caledonian continental collision zone: the role of eclogitization. Tectonophysics 273 , 129-153.

Bao, X., Eaton, D.W, Guest, B. 2014. Plateau uplift in western Canada caused by lithospheric delamination along a craton edge. Nature Geoscience 7, 830-833.

Beaumont, C., Nguyen, M., Jamieson, R., Ellis, S., 2006. Crustal flow modes in large hot orogens, in: Law, R.D., Searle, M.P., Godin, L. (Eds.), Crustal Flow, Ductile Extrusion and Exhumation in Continental Collision Zones. Geological Society, London, Special Publications 268, 91-145.

Beaumont, C., Ings, S.J., 2012. Effect of depleted continental lithosphere counterflow and inherited crustal weakness on rifting of the continental lithosphere: general results. Jounrnal of Geophysical Research, 117, B08407, doi: 10.1029/2012JB009203.

Boyd, O.S., Jones, C.H., Sheehan, A.F., 2004. Foundering lithosphere imaged beneath the Southern Sierra Nevada, California, USA. Science 305, 660-662.

Bürgmann, R., Dresen, G., 2008. Rheology of the lower crust and upper mantle: evidence from rock mechanics, geodesy and field observations. Annual Review of Earth and Planetary Science 36, 531-567.

Conrad, C. P., Molnar, P., 1999. Convective instability of a boundary layer with temperature-and strain-rate-dependent viscosity in terms of 'available buoyancy'. Geophysical Journal International 139, 51-68.

Cooper, C.M., Conrad, C.P., 2009. Does the mantle control the maximum thickness of cratons? Lithosphere 1, 67-72.

Currie, C.A., Hyndman, R.D., 2006. The thermal structure of subduction zone back arcs, Journal of Geophysical Research 111, B08404, doi: 10.1029/2005JB004024.

Currie, C.A., Ducea, M.N., DeCelles, P.G., Beaumont, C., 2015. Geodynamic models of Cordilleran orogens: gravitational instability of magmatic arc roots, in: DeCelles, P.G., Ducea, M.N., Carrapa, B., Kapp, P.A. (Eds.), Geodynamics of a Cordilleran orogenic 
711

712

713

714

715

716

717

718

719

720

721

722

723

724

725

726

727

728

729

730

731

732

733

734

735

736

737

738

739

740

741

742

743

744

745

746

747

748

749

750

751

752

753

754

755

756

system: the central Andes of Argentina and northern Chile. Geological Society of America Memoirs 212, 1-22.

Dana, J.D., 1875. Manual of Geology_-Treating of the Principles of the Science with special reference to American Geological History (second edition): New York, Ivison, Blakeman, Taylor, and Co., $843 \mathrm{p}$.

Doin, M.-P., Fleitout, L., Christensen, U., 1997. Mantle convection and stability of depleted and undepleted continental lithosphere. Journal of Geophysical Research 102, 2771-2787.

Fullsack, P., 1995. An arbitrary Lagrangian-Eulerian formulation for creeping flows and its application in tectonic models. Geophysical Journal International 120, 1-23.

Gao, S., Rudnick, R.L., Yuan, H.L., Liu, X.M., Liu, Y.S., Xu, W.L., Ling,W.L., Ayers, J.,Wang, X.C., Wang, Q.H., 2004. Recycling lower continental crust in the North China craton. Nature 432, 892-897. doi: 10.1038/nature03162.

Gleason, G.C., Tullis, J., 1995. A flow law for dislocation creep of quartz aggregates determined with the molten salt cell. Tectonophysics 247, 1-23.

Goes, S., Govers, R., Vacher, P., 2000. Shallow mantle temperatures under Europe from P and S wave tomography. Journal of Geophysical Research 105, 11,153-11,169.

Goes, S., van der Lee, S., 2002. Thermal structure of the North America uppermost mantle inferred from seismic tomography. Journal of Geophysical Research 107, B3, doi: 10.1029/2000JB000049.

Gorczyk, W., Hobbs, B., Gerya, T., 2012. Initiation of Rayleigh-Taylor instabilities in intracratonic settings. Tectonophysics 514-517, 146-155.

Hardebol, N.J., Pysklywec, R.N., Stephenson, R., 2012. Small-scale convection at a continental back-arc to craton transition: application to the southern Canadian Cordillera. Journal of Geophysical Research 117, B01408, doi: 10.1029/2011JB008431.

Hieronymus, C.F., Shomali, Z.H., Pedersen, L.B., 2007. A dynamical model for generating sharp seismic velocity contrasts underneath continents: application to the Sorgenfrei-Tornquist Zone. Earth and Planetary Science Letters 262, 77-91.

Hirschmann, M.M., Aubaud, C., Withers, A.C., 2005. Storage capacity of $\mathrm{H}_{2} \mathrm{O}$ in nominally anhydrous minerals in the upper mantle. Earth and Planetary Science Letters 236, 167181.

Hirth, G., Kohlstedt, D.L., 1996. Water in the oceanic upper mantle: implications for rheology, melt extraction and the evolution of the lithosphere. Earth and Planetary Science Letters 144, 93-108.

Hirth, G., Kohlstedt, D., 2003. Rheology of the upper mantle and the mantle wedge: a view from the experimentalists, in: Eiler, J. (Ed.), Inside the Subduction Factory. American Geophysical Union, Geophysical Monograph Series 138, 83-105.

Houseman, G. A., Molnar, P., 1997, Gravitational (Rayleigh-Taylor) instability of a layer with non-linear viscosity and convective thinning of continental lithosphere, Geophysical Journal International 128, 125-150.

Hu, S., He, L., Wang, J., 2000. Heat flow in the continental area of China: a new data set. Earth and Planetary Science Letters 179, 407-419.

Huismans, R.S., Beaumont, C., 2003. Symmetric and asymmetric lithosphere extension: relative effects of frictional-plastic and viscous strain softening. Journal of Geophysical Research 108, B10, 2496, doi: 10.1029/2002JB002016.

Huismans, R., Beaumont, C., 2011. Depth-dependent extension, two-stage breakup and cratonic underplating at rifted margins. Nature 473, 74-78, doi: 10.1038/nature09988. 
Hyndman, R.D., Lewis, T.J., 1999. Geophysical consequences of the Cordillera-Craton thermal transition in southwestern Canada. Earth and Planetary Science Letters 306, 397-422.

Hyndman, R.D., Currie, C.A., Mazzotti, S., Frederiksen, A., 2009. Temperature control of continental lithosphere elastic thickness, Te vs Vs. Earth and Planetary Science Letters 277, 539-548.

Kaban, M.K., Mooney, W.D., Petrunin, A.G., 2015. Cratonic root beneath North America shifted by basal drag from the convecting mantle. Nature Geoscience 8, 797-800, doi: $10.1038 /$ ngeo 2525 .

Karato, S.-I., 2008. Deformation of Earth materials: an introduction to the rheology of solid Earth. Cambridge University Press, 463 pp.

Karato, S.I., Wu, P., 1993. Rheology of the upper mantle: a synthesis. Science 260 (5109), 771778.

Karlstrom, K.E., Crow, R., Crossey, L., Coblentz, D., van Wijk, J., 2008. Model for tectonically driven incision of the younger than 6 Ma Grand Canyon. Geology 36, 835-838.

King, S.D., 2005. Archean cratons and mantle dynamics. Earth and Planetary Science Letters 234, 1-14.

King, S., Anderson, D.L., 1998. Edge-driven convection. Earth and Planetary Science Letters 160, 289-296.

Lee, C.-T., Luffi, P., Chin, E.J., 2011. Building and destroying continental mantle. Annual Reviews of Earth and Planetary Science 39, 59-90.

Lenardic, A., Moresi, L., Mühlhaus, H., 2000. The role of mobile belts for the longevity of deep cratonic lithosphere: the crumple zone model. Geophysical Research Letters 27, 12351238.

Lenardic, A., Moresi, L.N., Mühlhaus, H., 2003. Longevity and stability of cratonic lithosphere: insights from numerical simulations of coupled mantle convection and continental tectonics. Journal of Geophysical Research 108, B6, 2303. doi: 10.1029/2002JB001859.

Levander, A., Schmandt, B., Miller, M.S., Liu, K., Karlstrom, K.E., Crow, R.S., Lee, C.-T., Humphreys, E., 2011. Continuing Colorado Plateau uplift by delamination-style convective downwelling. Nature 472, 461-465.

Li, X., Zhu, P., Kusky, T.M., Gu, Y., Peng, S., Yuan, Y., Fu, J., 2015. Has the Yangtze craton lost its root? A comparison between the North China and Yangtze cratons. Tectonophysics 655, 1-14.

Li, Z.-X.A., Lee, C.-T.A., Peslier, A.H., Lenardic, A., Mackwell, S.J., 2008. Water contents in mantle xenoliths from the Colorado Plateau and vicinity: implications for the mantle rheology and hydration-induced thinning of continental lithosphere. Journal of Geophysical Research 113, B09210. doi: 10.1029/2007JB005540.

Lowe, C. Ranalli, G., 1993. Density, temperatures, and rheological models for the southeastern Canadian Cordillera: Implications for its geodynamic evolution. Canadian Journal of Earth Sciences 30, 77-93.

Mackwell, S.J., Zimmerman, M.E., Kohlstedt, D.L., 1998. High temperature deformation of dry diabase with application to tectonics on Venus. Journal of Geophysical Research 103 (B1), 975-984.

Poudjom Djomani, Y.H., O’Reilly, S.Y., Griffin, W.L., Morgan, P., 2001. The density structure of subcontinental lithosphere through time. Earth and Planetary Science Letters 184, 605621. 
802

803

804

805

806

807

808

809

810

811

812

813

814

815

816

817

818

819

820

821

822

823

824

825

826

827

828

829

830

831

Pysklywec, R.N., Beaumont, C., 2004. Intraplate tectonics: feedback between radioactive thermal weakening and crustal deformation driven by mantle lithosphere instabilities. Earth and Planetary Science Letters 221, 275-292.

Shahnas, M., Pysklywec, R., 2004. Anomalous topography in the western Atlantic caused by edge-driven convection. Geophysical Research Letters 31, L18611, doi:10.1029/2004GL020882.

Shapiro, S.S., Hager, B.H., Jordan, T.H., 1999. Stability and dynamics of the continental tectosphere. Lithos 48, 115-113.

Sleep, N.H., 2003. Survival of Archean cratonal lithosphere. Journal of Geophysical Research 108, B6, 2302, doi: 10.1029/2001JB000169.

Stern, T., Houseman, G., Salmon, M., Evans, L., 2013. Instability of a lithospheric step beneath western North Island, New Zealand. Geology 41, 423-426.

Tang, Y., Zhang, H., Ying, J., Su, B., 2011. Widespread refertilization of cratonic and circumcratonic lithospheric mantle. Earth-Science Reviews 118, 45-68.

van Wijk, J.W., van Hunen, J., Goes, S., 2008. Small-scale convection during continental rifting: evidence from the Rio Grande rift. Geology 36, 575-578.

van Wijk, J.W., Baldridge, W.S., van Hunen, J., Goes, S., Aster, R., Coblentz, D.D., Grand, S.P., $\mathrm{Ni}$, J., 2010. Small-scale convection at the edge of the Colorado Plateau: implications for topography, magmatism, and evolution of Proterozoic lithosphere. Geology 38, 611-614.

Wang, H., van Hunen, J., Pearson, D.G., Allen, M.B., 2014. Craton stability and longevity: the roles of composition-dependent rheology and buoyancy. Earth and Planetary Science Letters 391, 224-233.

Willett, S.D., 1999. Rheological dependence of extension in wedge models of convergent orogens. Tectonophysics 305, 419-435.

Wu, F.Y., Yang, J.H., Wilde, S.A., Zhang, X.O., 2005. Geochronology, petrogenesis and tectonic implications of the Jurassic granites in the Liaodong Peninsula, NE China. Chemical Geology 221, 127-156.

Zhao, L., Zheng, T.Y., 2007. Complex upper-mantle deformation beneath the North China craton: implications for lithospheric thinning. Geophysical Journal International 170, 1095-1099. 
Table 1. Material properties used in the reference model.

\begin{tabular}{|c|c|c|c|c|}
\hline & $\begin{array}{c}\text { Continental } \\
\text { Upper-Mid } \\
\text { Crust }\end{array}$ & $\begin{array}{l}\text { Continental } \\
\text { Lower Crust }\end{array}$ & $\begin{array}{c}\text { Mantle } \\
\text { Lithosphere }\end{array}$ & $\begin{array}{l}\text { Sublithospheric } \\
\text { mantle }\end{array}$ \\
\hline \multicolumn{5}{|l|}{ Plastic rheology } \\
\hline $\mathrm{C}_{\mathrm{o}}(\mathrm{MPa})$ & 20 & 0 & 0 & 0 \\
\hline$\varphi_{\text {eff }}^{\mathrm{a}}$ & $15-2^{\circ}$ & $15-2^{\circ}$ & $15-2^{\circ}$ & $15-2^{\circ}$ \\
\hline \multicolumn{5}{|l|}{ Viscous rheology } \\
\hline $\mathrm{f}$ & 5 & 0.1 & 1 & 1 \\
\hline Auni $\left(\mathrm{Pa}^{-\mathrm{n}} \mathrm{s}^{-1}\right)$ & $1.10 \times 10^{-28}$ & $5.05 \times 10^{-28}$ & $9.0 \times 10^{-20}$ & $9.0 \times 10^{-20}$ \\
\hline Сон $\left(\mathrm{H} / 10^{6} \mathrm{Si}\right)$ & $\mathrm{n} / \mathrm{a}$ & $\mathrm{n} / \mathrm{a}$ & 1000 & 1000 \\
\hline $\mathrm{r}$ & 0 & 0 & 1.2 & 1.2 \\
\hline $\mathrm{B}^{*}\left(\mathrm{~Pa}^{-\mathrm{n}} \mathrm{s}^{-1} \mathrm{H} / 10^{6} \mathrm{Si}^{\mathrm{r}}\right)^{\mathrm{b}}$ & $2.92 \times 10^{6}$ & $1.91 \times 10^{5}$ & $7.79 \times 10^{3}$ & $7.79 \times 10^{3}$ \\
\hline $\mathrm{n}$ & 4.0 & 4.7 & 3.5 & 3.5 \\
\hline $\mathrm{Q}\left(\mathrm{kJ} \mathrm{mol}^{-1}\right)$ & 223 & 485 & 480 & 480 \\
\hline $\mathrm{V}^{*}\left(\mathrm{~cm}^{3} \mathrm{~mol}^{-1}\right)$ & 0 & 0 & 11 & 11 \\
\hline \multicolumn{5}{|l|}{ Thermal parameters } \\
\hline $\mathrm{k}\left(\mathrm{W} \mathrm{m} \mathrm{m}^{-1} \mathrm{~K}^{-1}\right)$ & 2.5 & 2.5 & 2.5 & 2.5 \\
\hline $\mathrm{A}\left(\mu \mathrm{W} \mathrm{m} \mathrm{m}^{-3}\right)$ & 1.1 & 0.4 & 0 & 0 \\
\hline $\mathrm{c}_{\mathrm{p}}\left(\mathrm{J} \mathrm{kg}^{-1} \mathrm{~K}^{-1}\right)$ & 1250 & 1250 & 1250 & 1250 \\
\hline \multicolumn{5}{|l|}{ Density } \\
\hline$\rho_{o}\left(\mathrm{~kg} \mathrm{~m}^{-3}\right)$ & 2800 & 3000 & 3250 & 3250 \\
\hline $\mathrm{T}_{\mathrm{o}}\left({ }^{\circ} \mathrm{C}\right)$ & 627 & 627 & 1327 & 1327 \\
\hline$\alpha\left(\mathrm{K}^{-1}\right)$ & $3.0 \times 10^{-5}$ & $3.0 \times 10^{-5}$ & $3.0 \times 10^{-5}$ & $3.0 \times 10^{-5}$ \\
\hline \multicolumn{5}{|c|}{$\begin{array}{l}\text { a Strain-softening is incorporated through a decrease in } \varphi_{\text {eff }} \text { over accumulated strain of } 0.5 \text { to } 1.5 \text { (e.g., } \\
\text { Huismans and Beaumont, 2003). }\end{array}$} \\
\hline \multicolumn{5}{|c|}{${ }^{b} B^{*}=\frac{1}{2}\left(\frac{3^{(n+1) / 2}}{2}\right)^{-1 / n}\left(A_{\text {uni }} C_{O H}{ }^{r}\right)^{-1 / n}$} \\
\hline
\end{tabular}


837

838

839

840

841

842

843

844

845

846

847

848

849

850

\section{FIGURES}

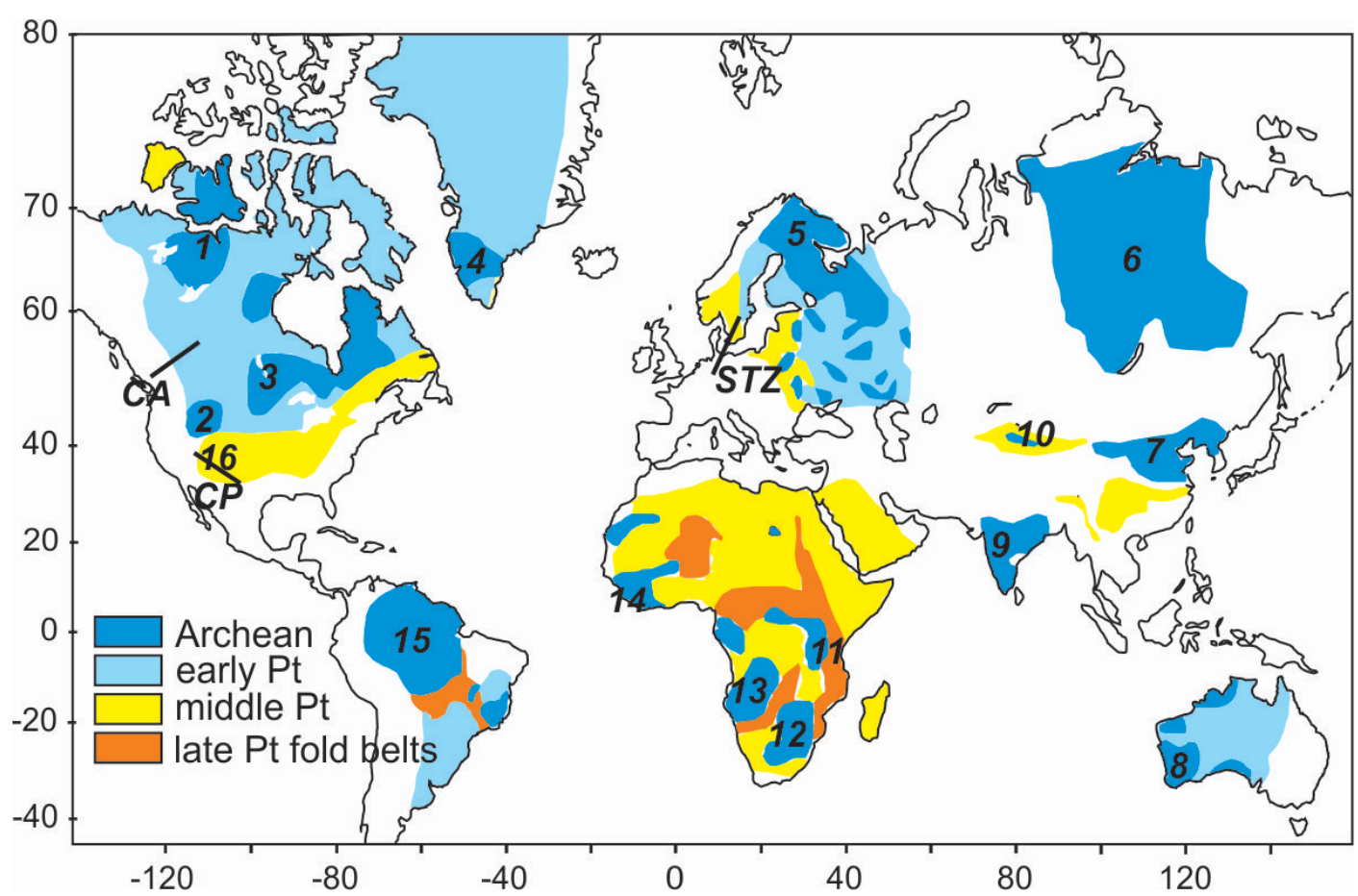

Figure 1. Age distribution of continental lithosphere (after Artemieva and Mooney, 2001). Archaean cratons and Colorado Plateau are numbered $(1-15,16)$. 1: Slave craton, 2: Wyoming craton, 3: Superior, 4: Greenland, 5: Fennoscandian, 6: Siberian, 7: North China craton, 8: west Australian, 9: Indian Shield, 10: Tarim, 11: Tanzanian craton, 12: Zimbabwe and Kaapvaal cratons, 13: Congo, 14: West African, 15: Amazonian, 16: Colorado Plateau. Locations of tomographic transects that are shown in Figure 2 are indicated: STZ is Sorgenfrei-Tornquist zone, $\mathrm{CP}$ is Colorado Plateau, and CA is western Canada. 
a) Sorgenfrei-Tornquist Zone

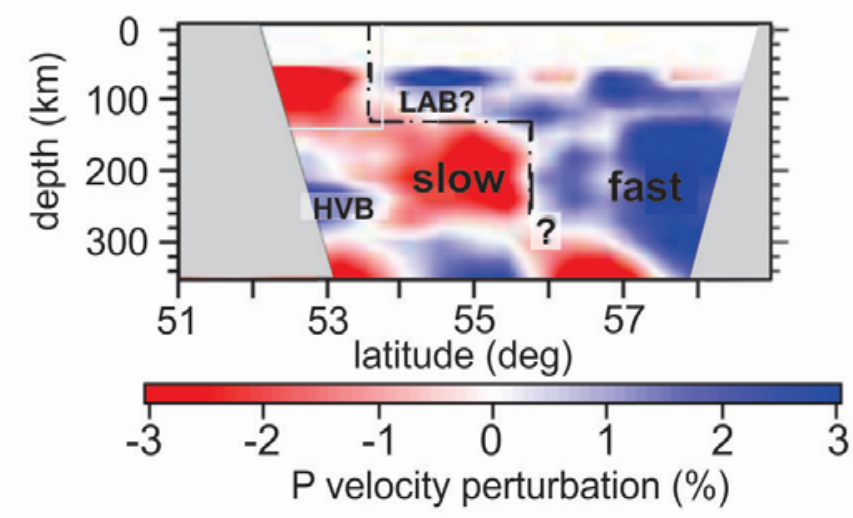

b) western Colorado Plateau

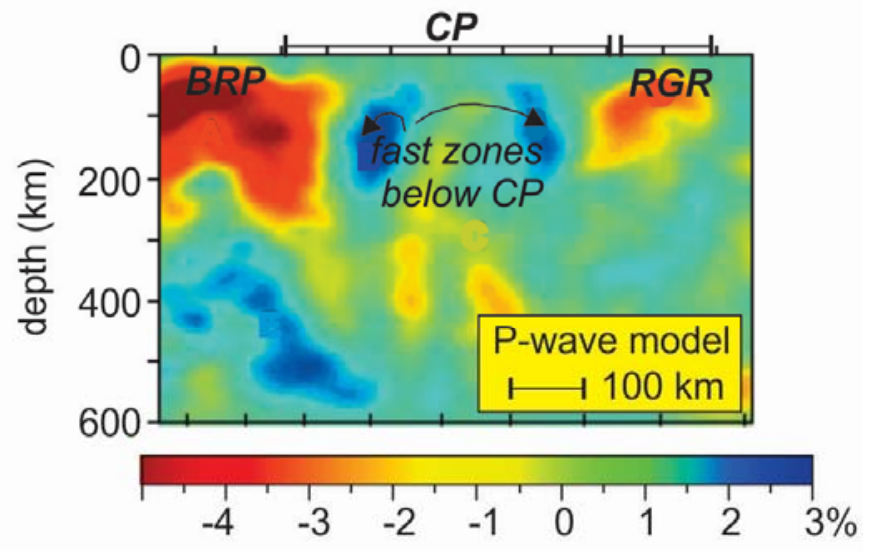

c) western Canada

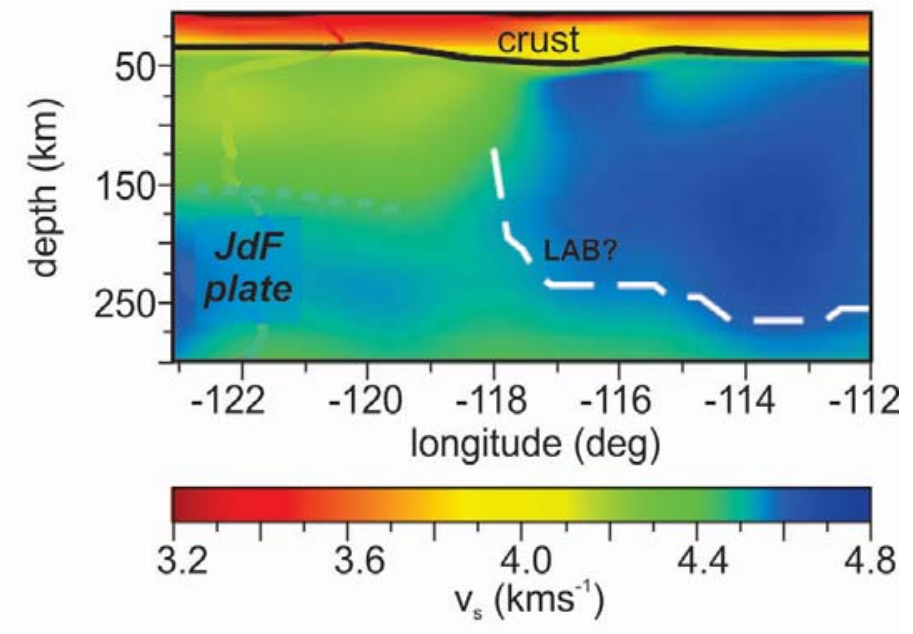

Figure 2. Seismic tomography images across: a) the Sorgenfrei-Tornquist Zone in northern Europe (after Hieronymus et al., 2007), b) the western Colorado Plateau (after Sine et al., 2008), and c) western Canada (after Bao et al., 2014). Profile locations are shown in Figure 1. LAB is lithosphere-asthenosphere boundary, HVB is high velocity block, BRP is Basin and Range Province, CP is Colorado Plateau, RGR is Rio Grande rift, JdF plate is Juan de Fuca plate. 


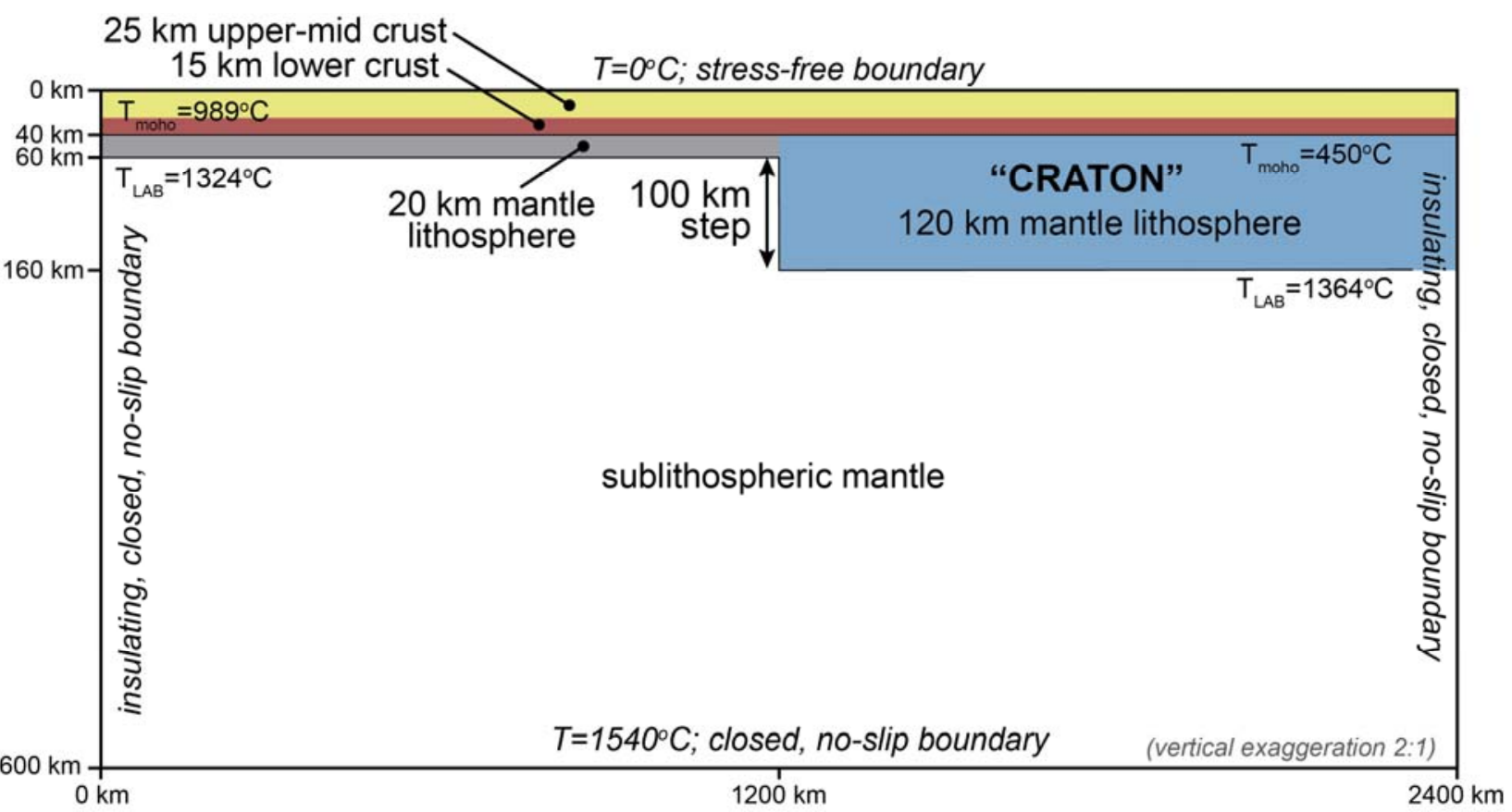

Figure 3. Initial geometry of the numerical models showing the distribution of materials and the thermal-mechanical boundary conditions.

\section{(NEXT PAGE)}

871 Figure 4. a) Initial geotherm applied to the $60 \mathrm{~km}$ thin lithosphere (red line) and $160 \mathrm{~km}$ thick lithosphere (black line). For each region, the lithosphere-asthenosphere boundary (LAB) corresponds to the intersection of the conductive geotherm with the mantle adiabat (grey line). The dashed blue line shows the maximum water content in olivine as a function of depth (Hirschmann et al., 2005). b) Initial density profile for the thin (red line) and thick (black line) lithosphere based on their temperature. The inset shows the density contrast relative to the sublithospheric mantle; this density contrast arises from differences in temperature only. c) Effective viscosity as a function of depth for the thin lithosphere (red) assuming damp olivine $(\mathrm{CoH}=1000 \mathrm{ppm} \mathrm{H} / \mathrm{Si})$ rheology and a strain rate of $10^{-15} \mathrm{~s}^{-1}$. Blue, black, grey and green lines show the effective viscosity for the thick lithosphere for water content ranging from dry to watersaturated. Rheologies are from Hirth and Kohlstedt (2003). d) The relative viscosity of the thick lithosphere for varying water content; the reference rheology is damp olivine $(\mathrm{COH}=1000 \mathrm{ppm}$ $\mathrm{H} / \mathrm{Si}$ ). e) Effective viscosity profiles for the weak (solid lines) and strong (dotted lines) thick lithosphere geotherm and a strain rate of $10^{-15} \mathrm{~s}^{-1}$. f) Relative viscosity of the rheologies in (e) compared to the reference damp olivine in (c). 
a)

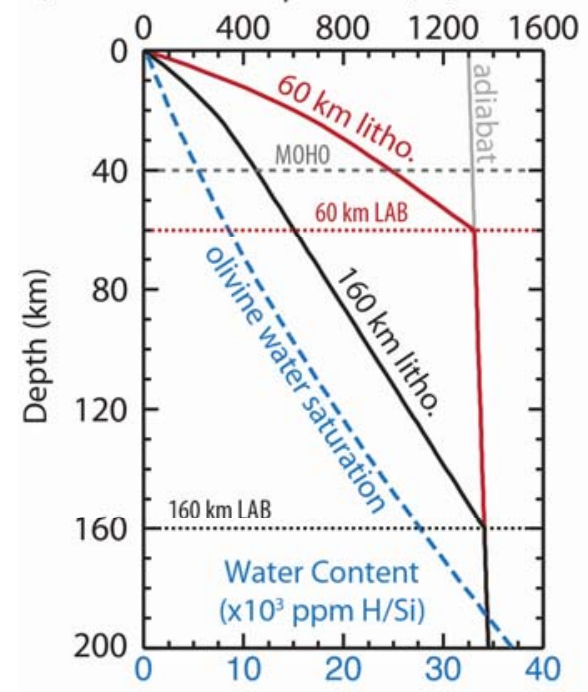

c)

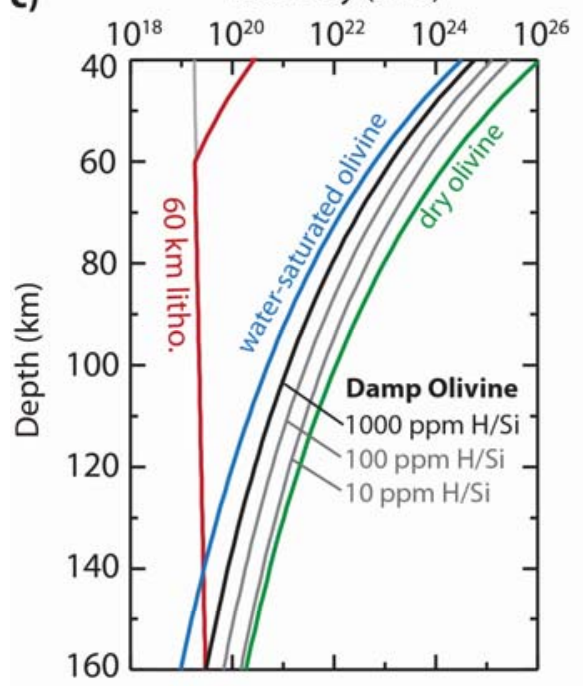

e)
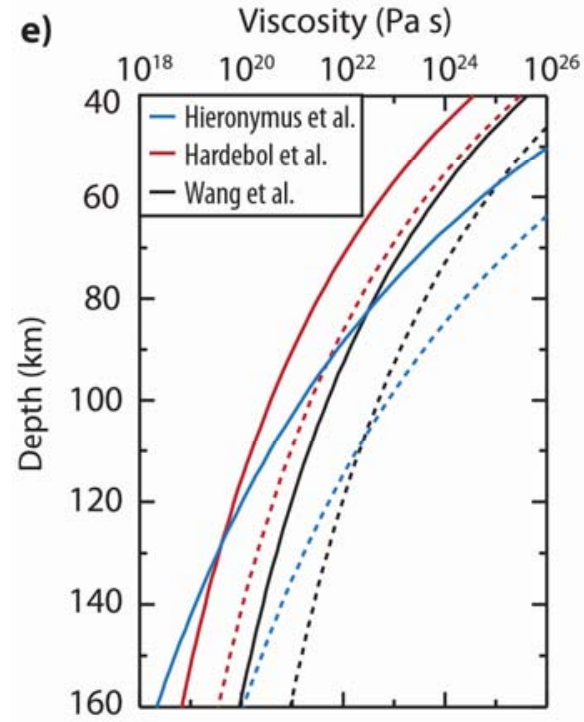

b) Density $\left(\mathrm{kg} / \mathrm{m}^{3}\right)$

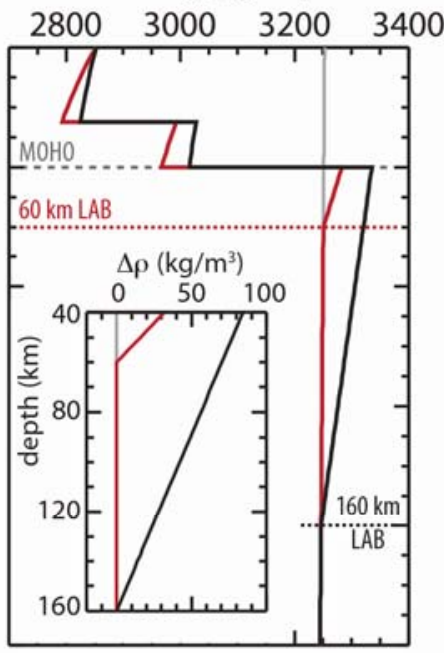

d) Relative Viscosity

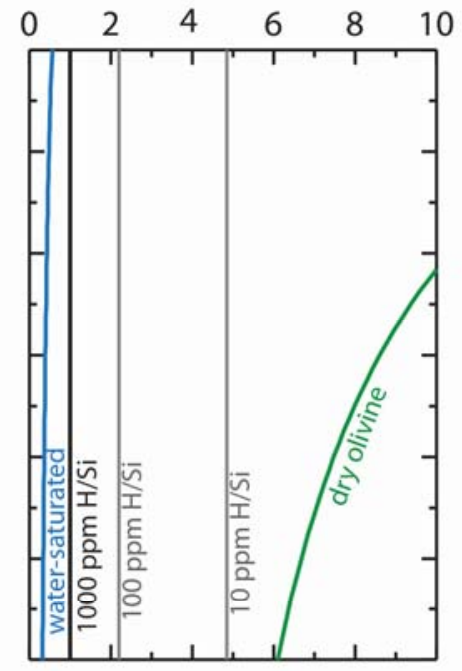

f) Relative Viscosity

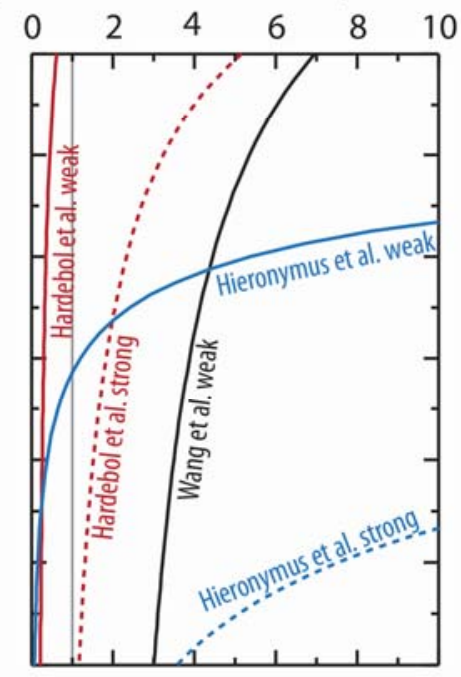

Fig. 4 


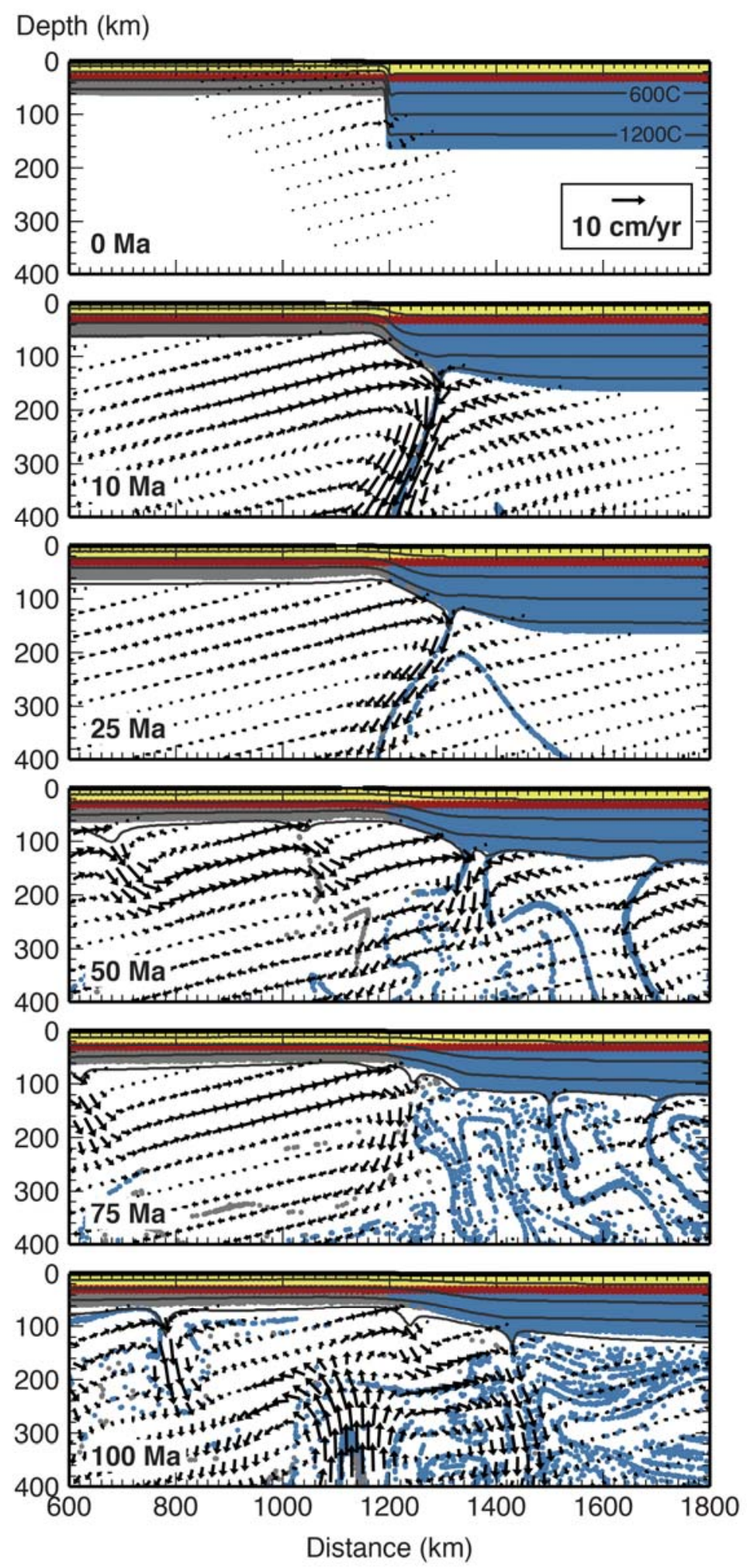

Distance $(\mathrm{km})$

Figure 5. Evolution of the reference model, in which the craton mantle lithosphere has the same reference density as the underlying mantle $\left(\Delta \rho=0 \mathrm{~kg} / \mathrm{m}^{3}\right)$ and a damp olivine rheology. Yellow

891 is upper crust, red is lower crust, and blue is mantle lithosphere material. Sub-lithospheric mantle 892 is white (Figure 3). Arrows indicate flow direction and magnitude. 


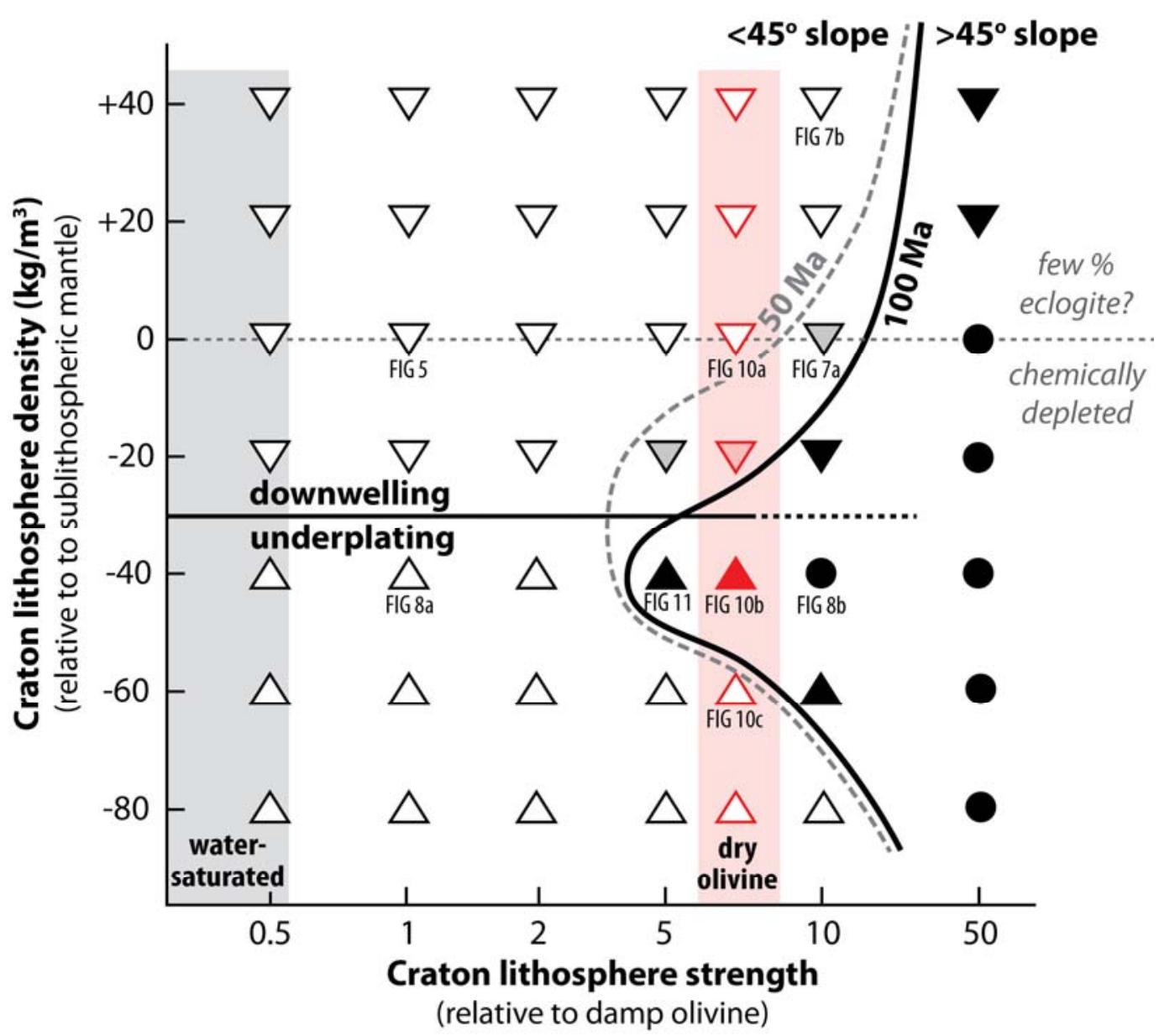

Figure 6. Regime diagram showing the behaviour of the lithosphere step for models in which the craton strength and compositional density are varied. Destabilization of the step occurs through either downwelling (downward triangles) or lateral spreading and underplating (upward triangles); circles denote models with little lithosphere destabilization. The dashed grey line and thick black line show the conditions that give a $45^{\circ}$ slope at the craton margin after $50 \mathrm{Ma}$ and $100 \mathrm{Ma}$, respectively. The craton strength was varied through a linear scaling of a damp olivine

900 rheology $(\mathrm{COH}=1000 \mathrm{ppm} \mathrm{H} / \mathrm{Si})$. Shaded grey region and shaded red region show the approximate strength of water-saturated and dry olivine, respectively (see Figure 4). 


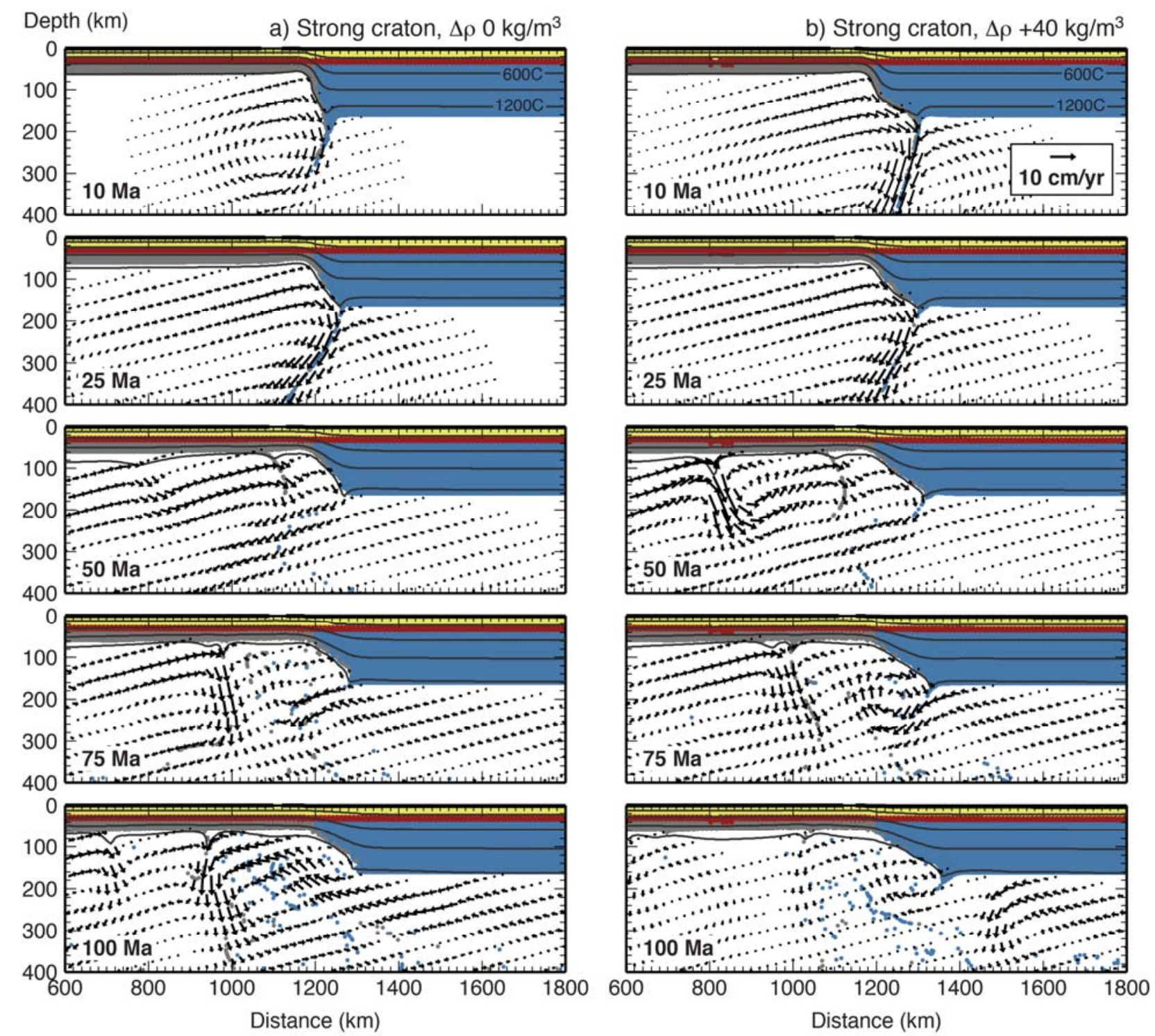

Figure 7. Evolution of models in which the craton lithosphere is 10 times stronger than the

905 reference damp olivine rheology. a) Craton mantle lithosphere has the same compositional

906 density as the underlying mantle. b) Craton mantle lithosphere compositional density is $20 \mathrm{~kg} / \mathrm{m}^{3}$

907 greater than that of the underlying mantle.

908 


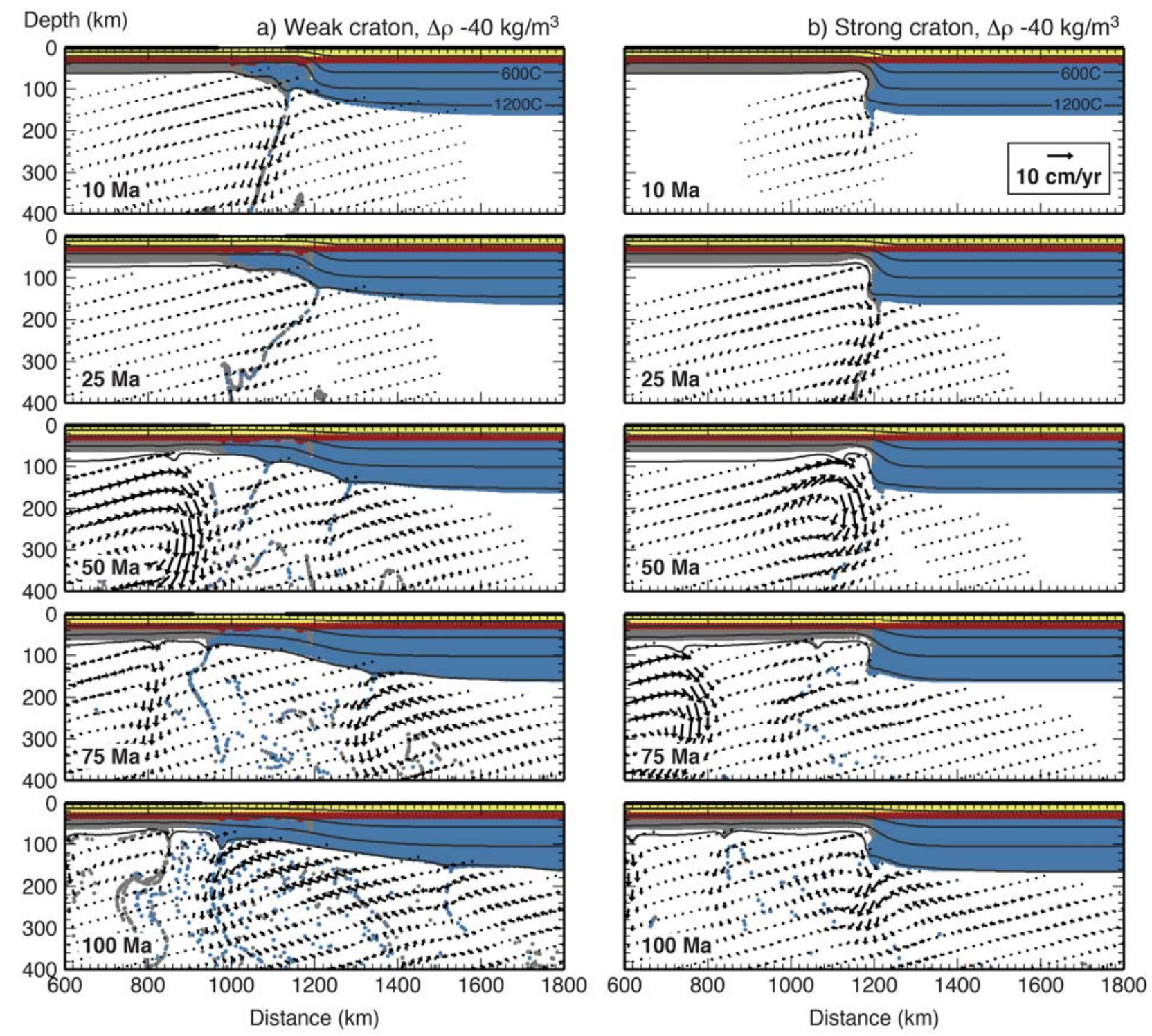

Figure 8. Evolution of models in which the craton lithosphere is compositionally buoyant (40

$911 \mathrm{~kg} / \mathrm{m}^{3}$ less dense than the underlying mantle). a) Craton mantle lithosphere has the reference

912 damp olivine rheology. b) Craton mantle lithosphere is 10 times stronger than the reference

913 rheology.

914 

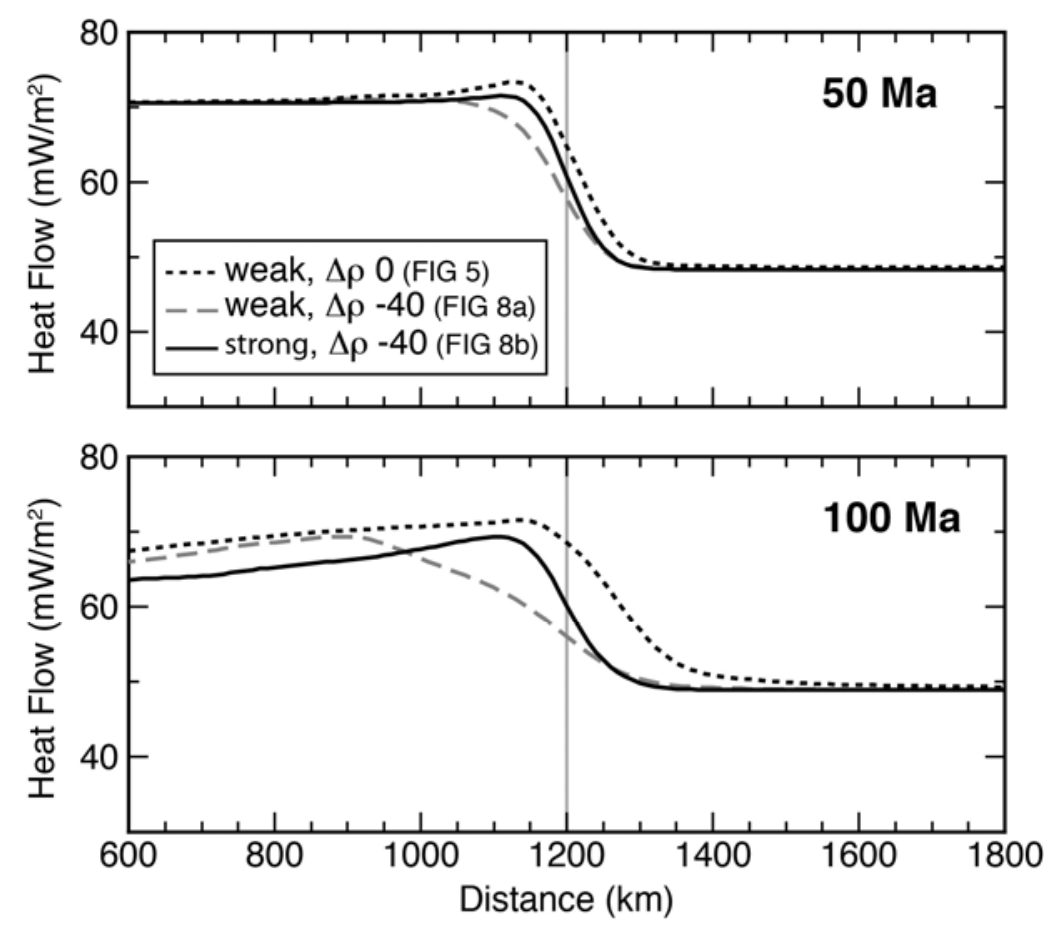

915
Figure 9. Surface heat flow at 50 and $100 \mathrm{Ma}$ for models that show the key three behaviours observed in our study: stable craton margin (solid line), craton margin destabilisation through downwelling (black dashed line) and destabilisation through underplating (grey dashed line). The vertical grey line is the original location of the craton margin. The legend gives the strength and compositional density contrast $\left(\Delta \rho\right.$, in $\left.\mathrm{kg} / \mathrm{m}^{3}\right)$ of the craton mantle for each model. The weak craton has the reference damp olivine rheology; the strong craton is 10 times stronger. 


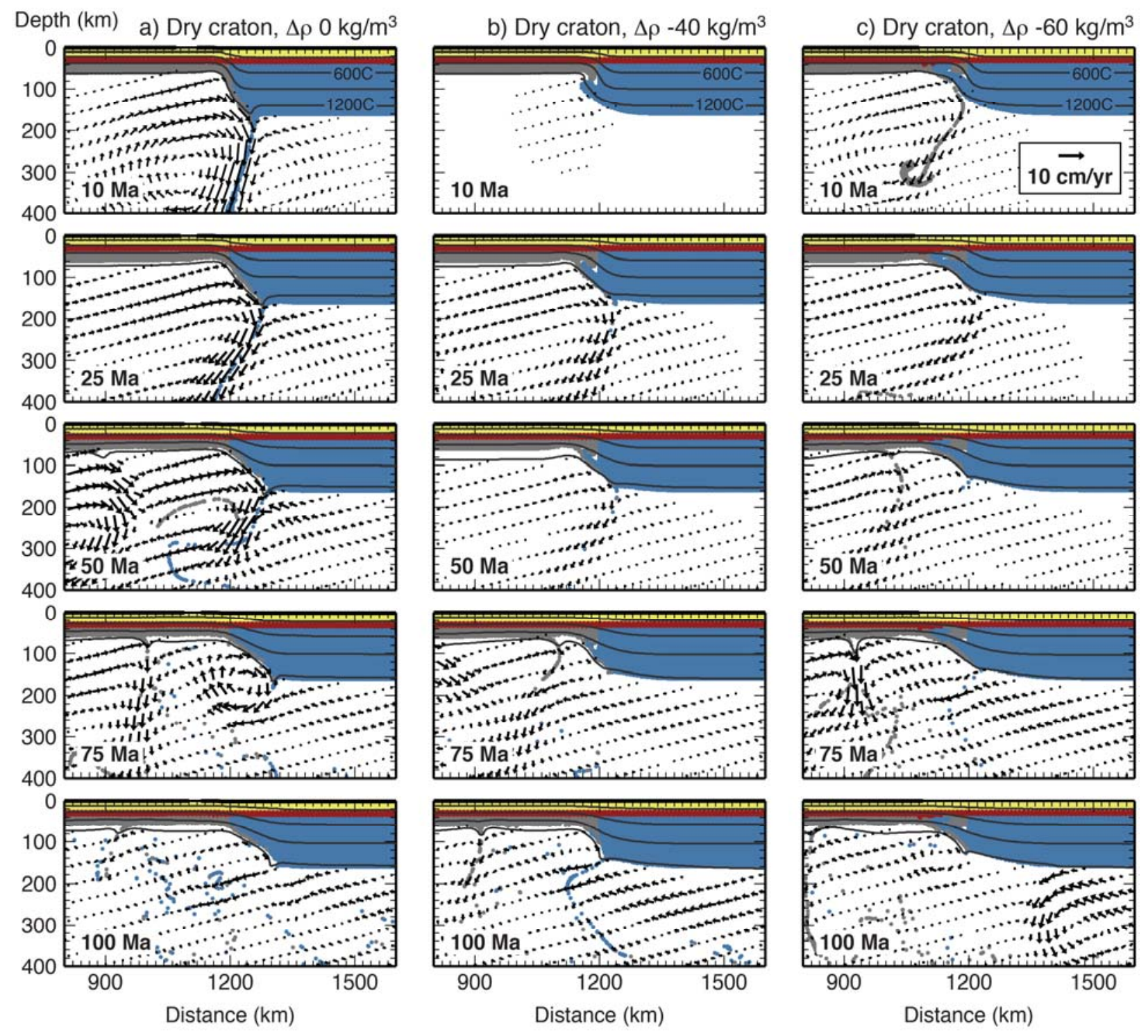

Figure 10. Evolution of models in which the craton lithosphere has a dry olivine rheology, and a 

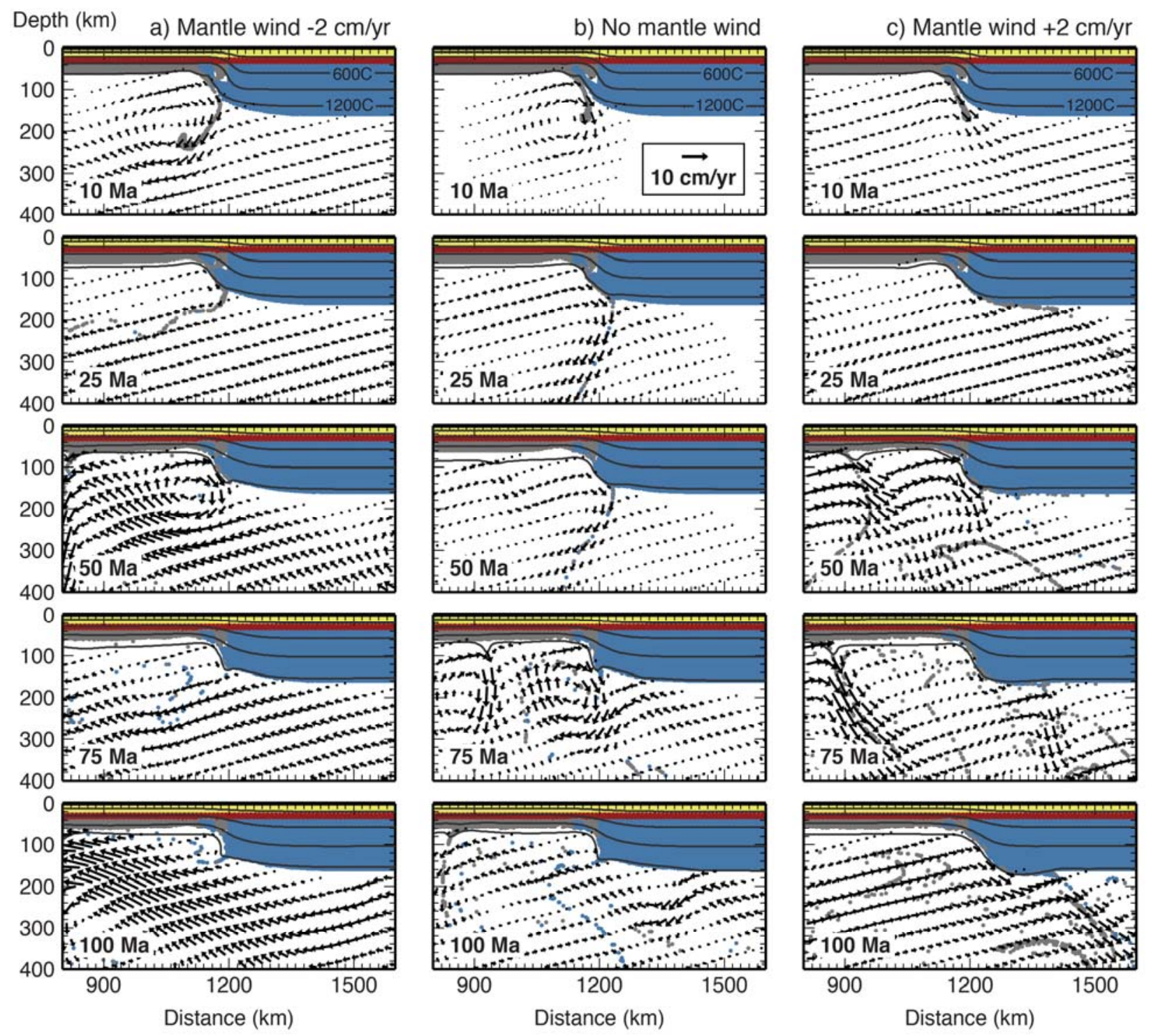

Figure 11. The effect of a mantle wind (horizontal mantle flow) on the behaviour of the

930 lithospheric step: a) $2 \mathrm{~cm} / \mathrm{yr}$ to the left, b) no mantle wind, c) $2 \mathrm{~cm} / \mathrm{yr}$ to the right. In all models,

931 the craton mantle lithosphere is 5 times stronger than the reference damp olivine and its

932 compositional density is $40 \mathrm{~kg} / \mathrm{m}^{3}$ less than that of the underlying mantle. 

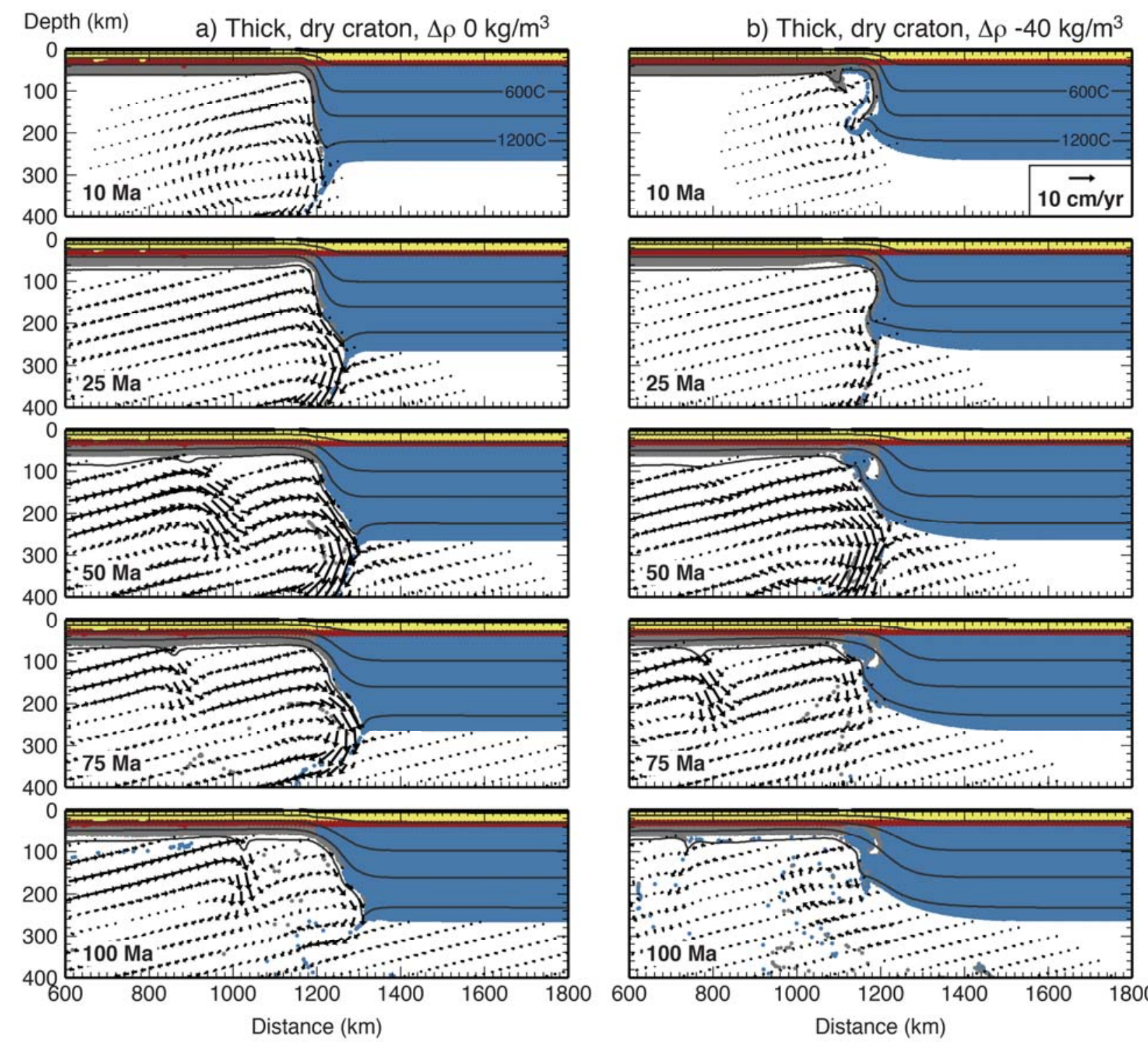

934 Distance $(\mathrm{km})$

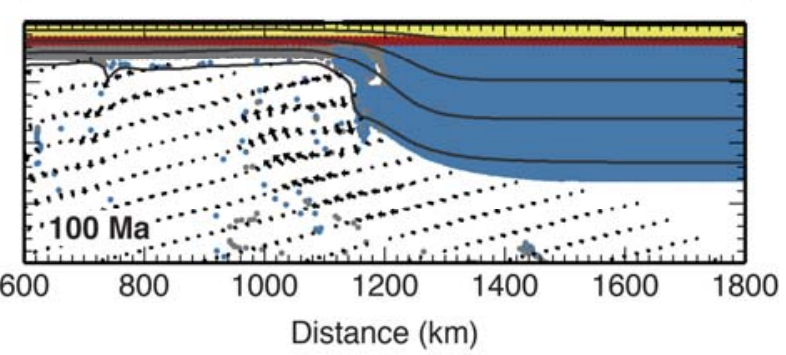

935 Figure 12. Evolution of models in which the craton lithosphere is $260 \mathrm{~km}$ thick with a dry 936 olivine rheology, and a compositional density that is: a) $0 \mathrm{~kg} / \mathrm{m}^{3}$ and b) $40 \mathrm{~kg} / \mathrm{m}^{3}$ less than that 937 of the underlying mantle. 